\title{
Multi-Senses Explication Activities Module for Dyslexic Children in Malaysia
}

\author{
Vijayaletchumy Subramaniam ${ }^{1}$, Vijay Kumar Mallan ${ }^{2} \&$ Noor Hayati Che Mat ${ }^{1}$ \\ ${ }^{1}$ Department of Malay Language, Faculty of Modern Languages and Communication, Universiti Putra Malaysia, \\ Selangor, Malaysia \\ ${ }^{2}$ Student Learning and Development, Higher Education Development Centre, University of Otago, Dunedin, \\ New Zealand \\ Correspondence: Vijayaletchumy Subramaniam, Department of Malay Language, Faculty of Modern Languages \\ and Communication, Universiti Putra Malaysia, Selangor, Malaysia. E-mail: letchumy1617@gmail.com
}

Received: February 7, 2013 Accepted: March 18, 2013 Online Published: June 1, 2013

doi:10.5539/ass.v9n7p241 URL: http://dx.doi.org/10.5539/ass.v9n7p241

\begin{abstract}
Dyslexic children are having abnormal difficulties in reading, spelling and writing. The awareness on these problems leads researcher to conduct a case study in the psycholinguistic field about the multi-senses explication activities in the words mastery among the dyslexic children in Sekolah Kebangsaan Padang Temu Melaka. Starting from the Information Processing Theory by Robert M. Gagne (1975) as the theoretical framework, this research aims to produce a module on the multi-senses explication activities for the dyslexic children in Malaysia. The subjects are five dyslexic children from Sekolah Kebangsaan Padang Temu Melaka. They are in the middle of following through the Dyslexia Specific Learning Problem Integration Programme in that particular school. Data were gathered from Test 1 and Test 2, questionnaire, interview sessions and observations conducted. The findings showed that the multi-senses explication activities could provide the language learning mode, especially on the mastery of the suitable words based on the dyslexic children's mind. Besides that, researcher also emphasized on the language game element in the students' learning of the Malay language. The interview sessions and the observations showed the improvised language learning game managed to pull the attention of the students and trigger the fun feelings of the dyslexic children in learning the Malay language which they felt difficult to master previously.
\end{abstract}

Keywords: multisenses, dyslexia, visual, auditory, kinesthetic and tactil

\section{Background of the Study}

\subsection{Characteristics of Dyslexia Children in Malaysia}

Dyslexia children have talent and specialty in arts because they are identified as having the inclination towards using their right side of the brain compared to the left. The usage of the right brain has the association with emotion, face recognition and determining the object structure. Therefore, the way these children think is always different from the normal ones. As a result, the dyslexia children will have difficulties in reading, spelling and writing (Ministry of Education Malaysia, 2003).

Basically, the education system would want to produce a balanced generation from the aspects of physical, spiritual, intellect and emotion. The quality of generation direct or indirectly will contribute to the formation of execellent generation (Muhammad et al., 2010). Sheila Devaraj \& Samsilah Roslan (2006), once stated that many dyslexia sufferers are talented in singing and music. Not forgetting, some of them even have talent in building and technical. According to the writers, they are many international companies out there looking for dyslexia candidates to fulfill the respective positions in the field of creation and building because to them these dyslexics have pure and unique way of thinking. Their talents are creative and they can even think literally and imaginatively. This can be proven by taking the historic personalities like Leornado Da Vinci, Thomas Alva Edison, Albert Einstein, John F. Kenndy and Auguste Rodin as examples (Ryden, 1998; Sheila. 2006).

Ronaldi Salleh et. Al. (2011) reported that the Malaysian Gorvenment is hoping that the people to master the competency of literacy 100 percent by 2020 . Nevertheles, the basic skills like reading, writing and calculting are difficult to obtain. This opinion is being supported by Julina Johan (2005) by saying that one of the contributing 
factors for these students to have problems in mastering basic skills like reading, writing and calculating at the primary school level is possessing a heavy cognitive memory development.

According to the International Dyslexia Association (2010), 10\% - 15\% of the world population is suffering from dyslexia. In Malaysia, the Department of Special Education Statistics, Ministry of Education Malaysia (Nor Afzan Mohammad Nor, 2006) estimated that 314,000 children in Malaysia are suffering from dyslexia. Komala Devi (2004), as the parliamentary secretary, Ministry of Education Malaysia reported that there were $5 \%$ of dyslexia cases detected in any community or one in every 20 students. This high population was also reported by the President of the Malaysia Harmonic Social Association (PSHM), Nordin Ahmad (2005) through the association research found that $10 \%-15 \%$ of the primary school children all over the country (majority are Malays) suffer from dyslexia. From the research done by the Federal Territory Association of Dyslexia (Sin Chew Daily, 2003), it was estimated that more or less there were $10 \%$ of the school children in Malaysia are dyslexia.

The blast of the 21 st century globalisation era has brought a new challenge in the language and communication literacy to a developing country like Malaysia (Koo, He \& Azman, 2010). It clearly shows that the syndrome is capable to stop the individual's ability to read and write and it can even go far from their real ability. Realizing this fact, Ministry of Education Malaysia has outlined a new programme known as the Dyslexia Specific Learning Problem Pioneer Programme to overcome the difficulties faced by these students. This programme exists because dyslexia occurs so oftenly here in Malaysia.

\subsection{Statement of the Problem}

There are many teaching and learning module in the market, but the materials are not suitable in terms of the ability, strength and interest of the dyslexic children in overcoming the problems of mastering the skills; reading, spelling and writing. Without the existence of the suitable learning module with the dyslexic children has open up a gap to the researcher to produce a learning module based on the use of multi-senses explication activities which incorporates the elements of visual, auditory, kinetic and tactic. This is in tandem with the researcher's objective to produce the use of multi-senses explication activities focusing on the dyslexic children.

\subsection{Objective of the Study}

To produce the multi-senses explication activities focusing on the dyslexia children.

\subsection{Significance of the Study}

1) Act as a learning source to enhance the language mastery of the dyslexia children especially in words that have the combination of dipthongs, vowels and consonants. It is hoped that all parties could accept and make use of the multi-senses explication activities to help teachers to attract attention of the dyslexia children towards Malay language subject which has been difficult to them. Therefore, teacher has to be proactive in taking up opportunity in making their teaching methods variable to create a meaningful learning environment (Mahamod \& Noor, 2011).

2) Is hoped to be able to help teachers to understand the relationaship between language when they use the multi-senses explication activities. The understanding is hoped to help them to improve their teaching methods especially in overcoming the language problem among the dyslexia children.

3) The activities are also for the parents to enhance and improve the usage of Malay language effectively. The rationale of this study can also be shared and practised by all organization for the betterment of the learning process of these dyslexia children.

4) The rationale in sharing this research can also be practised by other organization involved in the process of teaching the dyslexia children. For example the effectiveness and initiative of the researcher to produce the module of multi-senses explication activities can be implemented in the Intelligent Program had by the Universiti Kebangsaan Malaysia (UKM).

\section{Literature Review}

\subsection{Research on Charateristics of Dyslexia Children in Malaysia}

Nor hasbiah Abdullah (2010) has done a research on the multimedia course software in the mathematics literacy (D-Mathematics) for the dyslexia children. This research aims to develop the D-Mathematics software to motivate the mathematics literacy among the dyslexia children. The findings showed that the use of the D-Mathematics contains modules of learning numbers, addition, subtraction, multiplication, division, modules on times and some additional modules can motivate the dyslexia children in obtaining the mathematics literacy compared to the conventional method. This is also a software multimedia that uses Malay language to absorb the Scaffolding and Mnemonics $V-A$ models. 
Ronaldi Saleh et. al (2011) in his research on 'Usage of Animation in the Special Instruction for Dyslexia Children' has given the approach to create animation in the development of a learning object instruction which is based on interactive multimedia. The importance of the research involved the assessment on the learning objectives (LO) for the dyslexia children that have problems with numbers. The findings of the research showed that $90 \%$ of the students agreed to say that the LO has made them easier in understanding the multiplication concept through the story-telling activities. Whereas the other $90 \%$ of the respondents agreed to say that the content of the LO is suitable to their needs. He also suggested that before a module can be developed, researcher must refer to the characteristics of the dyslexia children, understand the statement of the problem carefully and identify the teaching methods.

\subsection{Research on Language Learning Problems among Dyslexia Children}

Nor Hasnizam Parman (1997) found that dyslexia children cannot pronounce the whole words and always face confusion among letters that are of the same shape. The findings of the study showed that the dyslexia children studied were retarded in their skills of making sounds of the letter, making errors in the arrangment of the letters and having confusion in identifying letters that look alike. Other than that, the children also were having visual problems when they failed to copy the words showed to them properly and auditory problems when they were making errors by writing wrong letters. These difficulties give high impact on the students' ability to read.

Mercer (1997) in his research explained that the dyslexia children are having difficulties in learning components of letters, words and sentences. In his study he has proven that the dyslexia children had problems in discriminating the letters 'b' from 'd' and ' $m$ ' from ' $w$ ', numbers '39 to 93' and ' 15 to 51' and words 'was' became 'saw' that look alike to sound alike. These children did not only have problems in differentiating letters that look alike but also in reading up words from sentences and sentences from paragraphs. This scenario can cause a low level of reading skills.

Shaywitz et al (1998), has conducted a study on the literacy inability of dyslexia children clinically by using the 105 image of Telsa Sigma MR onto 61 participants. They found that the dyslexia problem was closely related to the neurology since they were born. This also gave effect to the phonology arbitrarily. A set of 5-level ask was developed in the aspect of phonology like focus orientation test, letter focus, similarities of sound and letter, complex structure and semantics. This study used two experimental groups; dyslexia reader and non-dyslexia reader. Dyslexia reader failed to show systematic modulation while performing the task. The findings also found that the dyslexia reader faced mental and behaviour disorder that contribute to the reading problem. They were seriously having the neuro system problem that is related to the sense of sight and the effect was dyslexia did not able to connect letters and sounds. The dyslexia readers were not only failed to give meaning to symbol that they saw, but also to link the symbol with the utterances. These restraints caused them a failure to give meanings to any letters and words.

Noor Hayati Che Mat (2007) in her study found that the reading problems affect the dyslexia kids fluency in mastering the reading of the Malay language. From the 100 subjects taken from the Hulu Langat district, reading problem was the most serious and highest problem with the average percentage of 78.6 . Only $21.4 \%$ students could read. The findings also showed $99 \%$ of the subjects had some kind of intonation problems in their reading. This percentage is high and it was followed by $96 \%$ of children who could not read. There were $93 \%$ of the children who could not spell while reading and $62 \%$ of them skipped sentences when they read and $83 \%$ did not comprehend when they had been reading.

\section{Methodology}

The theory used by the researcher in this research was the Information Processing Theory by Robert M. Gagne (1975). The scope of the research was limited to the words that have dipthongs, vowels and consonants that are in combination. The subjects were 5 dyslexia children selected among the 8 to 9 years of age. The location was in Malacca, the state that runs the Dyslexia Specific Learning Problem Integration Programme. The research design was survey by using data collections like interview sessions and observations. The instruments used were questionnaire, Test 1 and 2, camera, video camera, multi-senses teaching aids and language games that use informal language/ creative. The data analysis was through frequency and percentages.

\section{Findings of the Study}

The learning based on the multi-senses explication activities is produced to help the researcher to come up with suitable activities for the dyslexia children. The learning process activities provided cover all senses; visual, auditory, kinetic and tactic that follow the level of thinking and ability of the respective dyslexia children.

This module is also to give information to improve the understanding of teachers towards the needs of the dyslexia 
children. Thus, researcher thinks that teachers and parents hold the responsibilities to instill their dyslexic children with reading and writing skills. The coorperation and commitment from both parties are important to ensure the dyslexia children could master the skills that are needed by them in possessing the knowledge. To gain the knowledge and the $3 \mathrm{M}$ skills, they have to undergo the suitable learning process in order to fulfill different proficiency levels in moving towards a more complete life.

Besides that, this module also aims to make the Dyslexia Specific Learning Problem Pioneer Programme happen by planning activities, methods, techniques and learning process that are more systematic in focusing more to children who have problems in Specific Dyslexia. Researcher has manipulated materials based on the multi-senses explication activities like VAKT, Gillingham and Fernald methods, methods that are suitable to be adopted onto the abilities of the dyslexia children in Malaysia.

Based on the interviews done, researcher found that teachers who teach the dyslexia children are facing challenges in teaching the Malay language. This module is hoped to help the teachers in making the language teaching effective.

From the pre-test, $100 \%$ of the dyslexia children tested were confused in differentiating the letter 'b' with ' $d$ ', 'n' with ' $u$ ', ' $m$ ' with ' $w$ ', and ' $p$ ' with ' $q$ '. This matter matters to the dyslexia children because they cannot differentiate the letters that look similar to them. This module could help the children in overcoming this problem. For example, to reduce the confusing problem and difficulties in differentiating the letters ' $b$ ' and ' $d$ ', teacher was asked to write ' $b$ ' in a big font by using the visual card. After that the teacher will ask the children to say the letter ' $b$ ' over and over again (drilling process). Next the teacher will ask the children to taste the letter ' $b$ ' with the rough-letter sponge card by using their index finger to shape the letter ' $b$ '. The children will then ask to shape the letter ' $b$ ' by using the clay provided until they can memorise them. The children then will be asked to connect the letters by using the connecting card provided. Last but not least the children are asked to sketch the letter by using the index finger on a paper. To get the touch effect while doing the sketch, the letters can be made from a sand paper, sponge, beads, 10 cent coin, rope, straw, or stretchable wire and write the letters by using sandy mould, flour, rice and others.

To learn the letter by using this method multi senses VAKT, a method that holds to the sensory principle in learning and standing on the premises of sensory towards sensitive multisensory to strengthen the learning. For example, dyslexia children see $(\mathrm{V})$ and then they are asked to listen to the teacher saying the letter (A). They children are then asked to say the letter (A). The children will also get to feel the muscles movement when they sketch (K). They then are asked to touch the surface of the letter (T) with their index finger. They need to see their hands movement when they sketch (V) and lastly they are asked to listen by themselves the sound of the sketched letter (A). After the lesson of the letter ' $b$ ' is over, the teacher could proceed with the letter ' $d$ ' and others. For a better understanding, researcher has provided varieties of the multi-senses explication activities module for the letter ' $b$ ', 'd', 'm', 'w', 'n', 'u', 'p', and 'q' as follows:

Multi-Senses Explication Activity 1

\begin{tabular}{lll}
\hline Subject & $:$ & Malay Language \\
Date & $:$ & \\
Time & $:$ & 60 Minutes (1 hour) \\
No. of Students & $:$ & \\
Title & $:$ & Letter ' $b$ ' \\
Skill & $:$ & 5.1 Moving hands without having pen or pencils. \\
Combination $\quad$ of & $:$ & 3.3 .1 Consonants Form and Sound \\
Skills & & 6.2 .1 Letter, syllable and word \\
Learning Outcome $\quad:$ & At the end of the lesson, students will be able to:- \\
& & $1 . \quad$ Know and name letter 'b' based on 'b' visual card. \\
& $2 . \quad$ Pronounce letter 'b' with correct pitch and intonation. \\
& 3. Shape letter 'b' with the clay. \\
& $4 . \quad$ Choose and identify letter 'b' only.
\end{tabular}




\begin{tabular}{lll}
\hline Method & $:$ Multi-senses \\
Across Curriculum & $:$ & Science, Arts, Mathematics \\
Value Absorbed & $:$ & Cooperation, Self confidence, Listen to instructions, Patience. \\
Therapy Elements & $:$ & Speaking, Touching, Work Ethics, Focus. \\
Teaching Aids & $:$ & Work template, letter 'b' puzzle, ball, small ball, congkak, balloon, letter visual card, clay and \\
& mystery box. \\
\hline
\end{tabular}

\begin{tabular}{ll}
\hline \multicolumn{1}{c}{ Step } & Mystery box. \\
Set & Clue:- \\
(5 minutes) & Normally, we kick it by using \\
& our leg. \\
Guess what am I? & Answer:- \\
Introduce the letter ' $b$ ' with a \\
balloon.
\end{tabular}

Show letter 'b' card

Step 2 Feel the letter 'b' by using the

(6 minutes) visual card made of 10 cent coins.

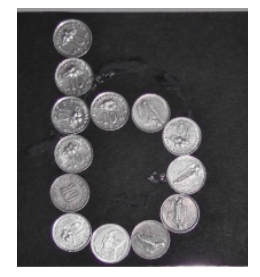

\section{Teaching and Learning Activities}

1. Student is given the mystery box. (V)

2. Teacher gives students the ckues. (A)

3. Students must touch the object by using their hands inside the mystery box. (T)

4. Teacher relates 'ball' with the title to the lesson- learning of the letter ' $b$ '.

(a)

(20)

\section{Remarks}

\section{Method:}

Guessing game.

Multi-senses (V,A,T)

Therapy:

Speech, rough motor.

Value:

Listening for

instructions, patience

Teaching Aids:

Mystery box and ball

\section{Method:}

1. Students are given a balloon that has a letter 'b' inside it. (V)

Multi-senses

$(\mathrm{V}, \mathrm{K}, \mathrm{A}, \mathrm{K})$

2. Students are asked to burst the balloon to get the letter. (K -A)

Therapy:

3. Students must collect the letter ' $b$ ' $(K)$

Speech

4. Then, students are asked to write the letter

' $b$ ' in the air by using their index finger. (K)

Value:

Cooperation

Teaching Aids:

Balloon and letter ' $b$ ' card

\section{Method:}

1. Teacher distributes the letter ' $b$ ' card made of 10 cent coins. (V)

Multi-senses

(V,T,K,A)

2. After that, students must feel the letter ' $b$ ' by using their index fingers onto the surface of the

Therapy: coins while tracing the letter. (T-K)

Soft motor

Value:

3. Students are asked to repeat the activity while mentioning the letter ' $b$ '. (A)
Following instructions and careful

\section{Teaching Aids:}

10 cent coins letter card 
Step 3 Form the letter ' $b$ ' by using

(8 minutes) clay.
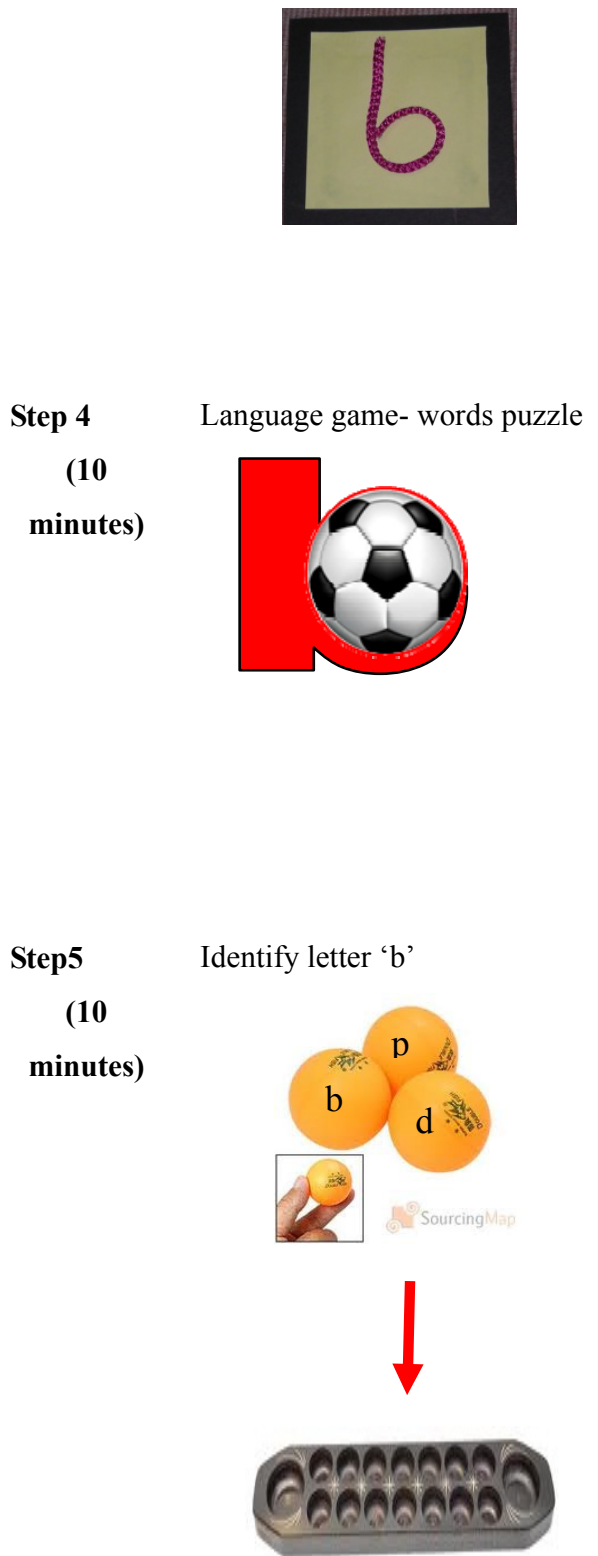

Step 6

(10 minutes)
Enhancement activity and work

$$
\text { template }
$$

letter ' $b$ '.

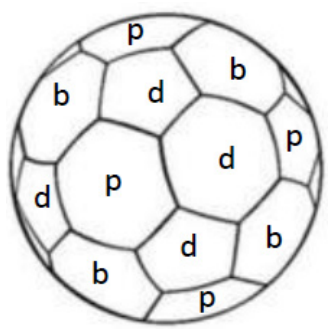

1. Teacher gives clay to the students. (V)

2. Teacher demonstrates how to form the letter 'b' with the clay. (V)

3. Students must form the letter ' $b$ ' individually by using the clay. (K-T)

4. Students must pronounce the letter ' $\mathrm{b}$ ' one by one. (A).

1. Each student is given a puzzle with a shape of 'b'.

2. Students are asked to see and connect the puzzle to form the letter ' $b$ '. (V-K)

3. After it's done, students must repeat the letter ' $b$ ' over and over again. (A)

4. Weak students will be facilitated by the teacher.

5. Teacher shows the outcome of the puzzle and gives star due to students achievement.

1. Students are given a congkak and a small ball marked ' $b$ ' and ' $d$ and ' $p$ ' mixed in the big hole of the congkak.

2. students are asked to identify and put aside only the letter ' $b$ 'from the Murid dikehendaki mengecam dan mengasingkan huruf ' $b$ ' big hole of the congkak. (V-K)

3. After that, students must put the small ball marked with the letter ' $b$ ' into the Selepas itu, murid dikehendaki memasukkan bola bersaiz kecil yang bertanda huruf 'big hole of the congkak (K)

4. Teacher will guide the weak students and compliment those who are successful in separating the letter correctly.

1. Students are given work template each.

2. Students are asked to find and select letter ' $b$ ' inside the picture. (V)

3. Students are asked to colour only the letter 'b'. (K)

4. After it's done, students must say the letter 'b' over and over again..(A)

5. Students who are successful in settling the task, will be given a smile sticker.

\section{Method:}

Multi-senses (V,K,A)

Therapy:

speech

Value:

Cooperation, Listen to instructions

\section{Teaching Aids:}

Clay

\section{Method:}

Multi-senses

gameV,K,A)

Therapy:

Soft motor, focus

Value:

Listen to instructions, patience

Teaching Aids:Letter 'b' puzzle set

\section{Method:}

Multi-senses V,K)

Indentifying

Therapy:

Observing working technique

Value:

Listen to instructions

Teaching

Aids

Marked congkak and small ball.

\section{Method:}

Multi-senses.(V,K,A)

Therapy:

Soft motor and working technique.

Value:

Listen to instructions, hardworking

Teaching Aids work template. 
Conclusion Conclusion and throwing and

(5 minutes) catching a ball activity

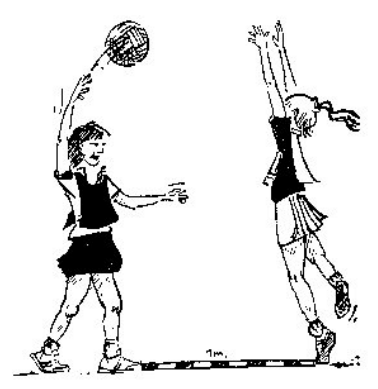

\section{Method:}

1. Students are divided into pairs.

2. Students are asked to throw and catch the ball while saying the letter ' $b$ ' repeatedly. $(A, K)$

3. Teacher asks questions to students. (A).
Multi-senses.(A,K)

Therapy:

Soft motor and working technique.

Value:

Listen to instructions, hardworking

Teaching Aids

Ball.

Multi-Senses Explication Activity 2

\begin{tabular}{lll}
\hline Subject & $:$ & Malay Language \\
$\begin{array}{l}\text { Date } \\
\text { Time }\end{array}$ & $:$ & 60 Minutes (1 hour) \\
No. of Students & $:$ & \\
Title & $:$ & Letter 'd' \\
Skill & $:$ & 5.3 Doing eyes and hands coordination \\
Combination of Skills & $:$ & 3.3 .2 Label, symbol and easy printed materials \\
& 6.1 .1 Vowel and consonants forms and sounds \\
Learning Outcome & $:$ & At the end of the lesson, students will be able to:- \\
& 1. Know and name letter 'd' based on 'b' visual card. \\
& 2. Pronounce letter 'd' with correct pitch and intonation. \\
& 3. Write letter 'd' on the surface of the yellow rice.. \\
& 4. Differentiate letter 'd' with 'b' by using hand symbol. \\
Teaching Aids & $:$ & Multi-senses \\
Method & $:$ & Science, Arts \\
Across Curriculum & $:$ & Cooperation, Self confidence, Listen to instructions, Patience. \\
Value Absorbed & $:$ & Speaking, Touching, Work Ethics, Focus. \\
Therapy Elements & Dice, rice, bowling pin, ball, letter card, mirror, sticker, work template and fingers. \\
\hline
\end{tabular}

\begin{tabular}{llll}
\hline \multicolumn{1}{c}{ Step } & \multicolumn{1}{c}{ Teaching and Learning Activities } & \multicolumn{1}{c}{ Remarks } \\
\hline Set & Dice model & 1. Students are showed the dice model by the & Method: \\
teacher. (V) & 2. Teacher showed word 'dice' to the students and & Therapy: \\
students are asked to count how many letters 'd' & Speech \\
(5 minutes) & are there in the word? (A, K) & Value: \\
3. Teacher is asking and answering questions with & Listen to & instructions, \\
students. (A) & 4. Teacher connects the letter 'd' with the dice. (A) & Teaching Aids Dice \\
5. Students say the word 'd' = dice repeatedly. (A) & 6. Teacher connects the title learnt with the letter & \\
'd'.
\end{tabular}


Step 1 Introduce letter ' $d$ ' by (6 minutes) using the visual ' $\mathrm{d}$ card.

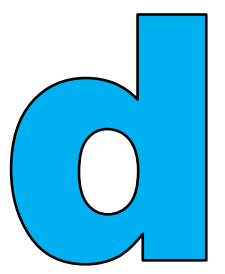

Step 2

(6 minutes)

Feel the letter 'd' with

letter card sponge



Step 3

Write the letter 'd'on the

(8 minutes) yellow rice surface.



Before

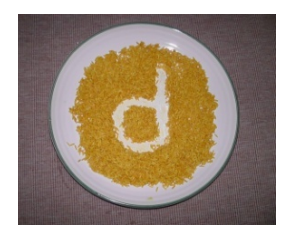

After

Step 4 Differentiate letter ' $d$ ' and

(10 'b by using hand symbol. minutes)
1. Students are showed the visual card with a letter 'd'.(V)

2. Teacher says the letter ' $d$ '. (A)

3. Students must say the letter 'd' with the pitch and intonation repeatedly in front of the mirror.

4. Students must be given the visual card letter ' $d$ ' and are asked to trace the letter follow the shape of the letter ' $d$ '. (K)

1. Students are asked to say the letter ' $d$ ' repeatedly. (A)

2. Teacher gives the letter ' $d$ ' to the students.

3. Students are to see the feel the letter 'd' with their index fingers while surfing the letter. (V-T) 4. Students are to pronounce the letter ' $d$ ' while clapping their hands. (A-K)

1. Teacher provides yellow rice on a plate.

2. Students are to come forward to see what teacher writes - letter ' $d$ '. (V).

3. Each student is given a plate of yellow rice.

4. Students are asked to write the letter ' $d$ ' by using the index fingers onto the surface of the yellow rice. $(\mathrm{K})$

. Teacher demonstrates the symbol by using the hands. (V)

2. Students is required to follow the hand symbols of the letter ' $b$ ' and ' $d$ '. (K)

3. Students must say the letter while making the symbol ' $d$ ' with their right hand and ' $b$ ' with Left hand symbolizes ' $b$ ' their left hand repeatedly. (A)

\section{Method:}

Multi-senses.(V,K,A)

\section{Therapy:}

Soft motor and working technique.

Value:

Cooperation

Teaching Aids Letter card and mirror.

\section{Method:}

Multi-senses.(A,V,T,Kand drilling

Therapy:

Speech and focus

Value:

Cooperation, listen to instruction

Teaching Aids sponge letter card

\section{Method:}

Multi-senses.(V,K)

Therapy:

Soft motor

Value:

Cooperation, listen to instruction

Teaching Aids Rice

\section{Method:}

Multi-senses.(A,V,K)

Therapy:

Soft motor

Value:

Hardworking, listen to instruction and patience

Teaching Aids fingers

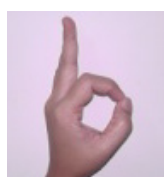



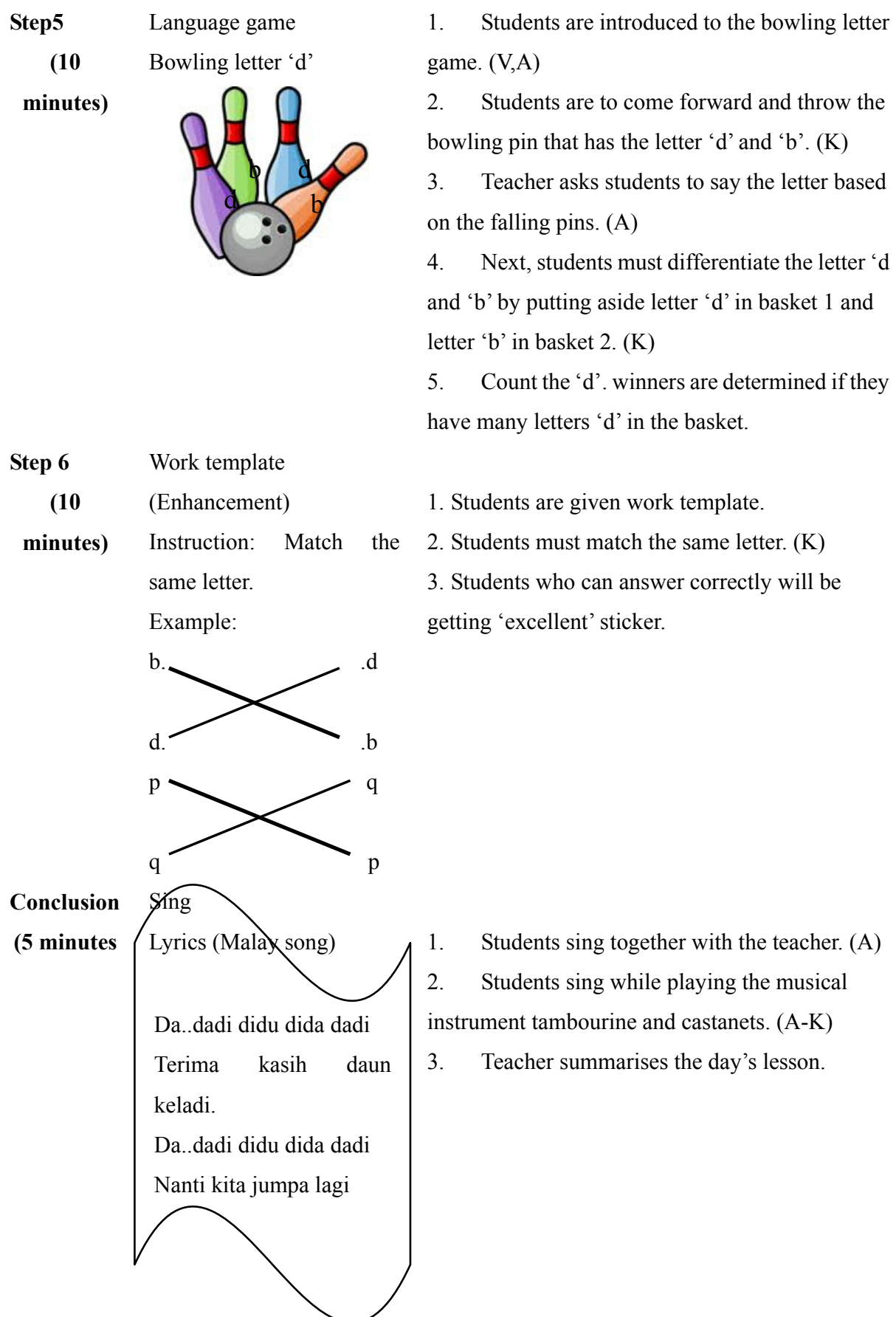

1. Students are introduced to the bowling letter game. $(\mathrm{V}, \mathrm{A})$

2. Students are to come forward and throw the bowling pin that has the letter 'd' and ' $b$ '. (K)

3. Teacher asks students to say the letter based on the falling pins. (A)

4. Next, students must differentiate the letter ' $\mathrm{d}$ and ' $b$ ' by putting aside letter ' $d$ ' in basket 1 and letter ' $b$ ' in basket 2. $(\mathrm{K})$

5. Count the ' $d$ '. winners are determined if they have many letters ' $d$ ' in the basket.

\section{Method:}

Multi-senses.(K)

Therapy:

Soft motor, colour

Value:

Cooperation, listen to instruction,

Teaching Aids work template, execellent word sticker.

\section{Method:}

Multi-senses.(A,K)

Therapy:

Speech

Value:

Cooperation, self

\section{Multi-Senses Explication Activity 3}

\begin{tabular}{|c|c|}
\hline Subject & : Malay Language \\
\hline Date & : \\
\hline Time & : 60 Minutes (1 hour) \\
\hline No. of Students & : \\
\hline Title & : Letter 'm' \\
\hline Skill & : 5.1.1 Moving of hands, wrists and fingers \\
\hline Combination of & : $\quad$ 3.3.2 Label, symbol and easy printed materials \\
\hline Skills & 6.1.1 Vowel and consonants forms and sounds \\
\hline
\end{tabular}


Learning Outcome : At the end of the lesson, students will be able to:-

1. Know and name letter ' $m$ 'correctly.

2. Identify and classify letter by using a table tennis ball labeled with the letter ' $m$ '.

3. Form letter ' $m$ ' with the red stretchable wire.

4. Differentiate letter ' $m$ ' with the McDonald's symbol.

\begin{tabular}{lll} 
Method & $:$ & Multi-senses \\
Across Curriculum & $:$ & Science, Arts \\
Value Absorbed & $:$ & Cooperation, Self confidence, Listen to instructions, Patience, Hardworking, Clean and Healthy \\
& & lifestyle \\
Therapy Elements & $:$ & Soft and hard motor and colours. \\
Teaching Aids & $:$ & Photo card, letter card, fake moustache, window card, colour paper, work template. \\
\hline
\end{tabular}

\begin{tabular}{ll}
\hline \multicolumn{1}{c}{ Step } & Content \\
\hline Set & Fake moutache \\
Induction & \\
(5 minutes) &
\end{tabular}

Step 1

Introduce the consonant ' $m$ '

(6 minutes) Use the Mc Donald symbol

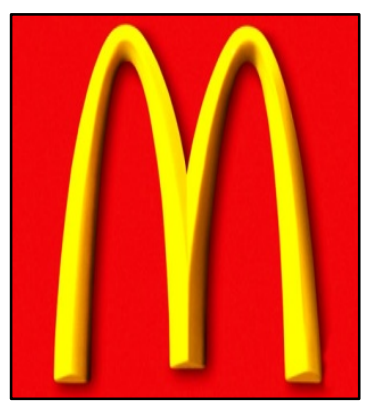

Step 2

Name the parts of body that starts with the

(6 minutes) letter ' $m$ '.

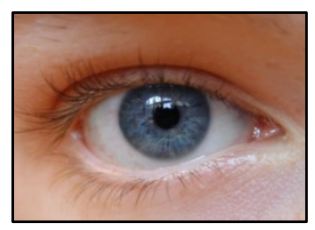

Teaching and Learning Activities

1. Teacher is wearing the fake

moustache and while facing her back to the children.

2. Students must watch the teacher as she turns herself facing the students.

3. Students say the weird thing that they see.

4. Teacher connects to the title to be learnt today- letter ' $m$ '.

1. Students are introduced the letter ' $\mathrm{m}$ by the teacher by using the symbol Mc Donald.(V)

2. Students are asked to watch carefully the symbol pasted in front of them. (V).

3. Students sketch the letter ' $m$ ' in the air while watching the Mc Donald symbol that represents the letter ' $m$ '.

(K-V).

4. Students sketch the letter ' $m$ ' in the air without looking at the letter.(K)

1. Students are asked to watch the window card pasted by the teacher. (V)

2. Students one by one will open the card abd guess the picture inside it. (K)

3. Students are to say the name of the body parts contain the card. (A)

4. Teacher connects the body parts with eye, mouth, face and moustache with the letter ' $m$ '.

\section{Remarks}

Method:

Multi-senses.(A,K)

Therapy:

Psychomotor

Value:

Teaching Aids:

Fake moutache

\section{Method:}

Multi-senses.(V,K)

Therapy:

Value:

Listen to instructions and cooperation

Teaching Aids:

Picture card

\section{Method:}

Multi-senses.(V,K, A)

Therapy:

Colour

Value:

Self confidence,

healthy lifestyle

Teaching Aids:

Window card 
Step 3 Shape the letter ' $\mathrm{m}$ ' by using the

(8 minutes) stretchable wire red in colour



Box that has the table tennis balls

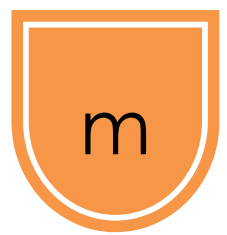

Bowl 'm'

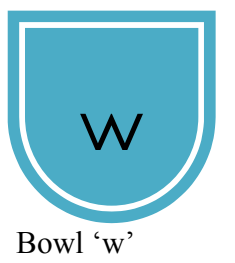

Step5 Language game

(10 Catch the little duck marked ' $\mathrm{m}$ ' fromm minutes) the pool.
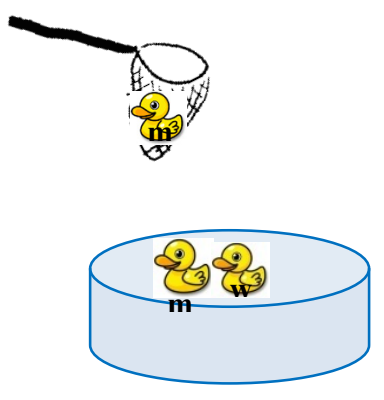

1. Each person is given a piece of a red stretchable wire.

2. Students are to shape the letter ' $\mathrm{m}$ ' with the red wire.

3. Students paste the letter ' $m$ ' onto the hard paper black in colour. $(\mathrm{K})$

4. Students touch the surface an say the letter ' $m$ ' correctly.(T-A)

1. Students are given a box that has tennis table balls.

2. The balls are marked ' $m$ ' and w'.

3. Students send the box to their friends and the music begins. $(\mathrm{K})$

4. When the music stops, the person who has the box picks up one table tennis ball. $(\mathrm{K})$

5. The student is asked to say the letter. (A)

6. The student is asked to put the ball in the box marked ' $m$ ' or ' $w$ '. (K).

\section{Method:}

Multi-senses.(K, T, V)

\section{Therapy:}

Soft and hard motor.

Value:

Hardworking

Teaching Aids:

Stretchable wire, hard paper and glue

\section{Method:}

Multi-senses.(K, A)

Therapy:

Focus

Value:

Patience

Teaching Aids:

Table tennis ball, paper bowl

bowl 


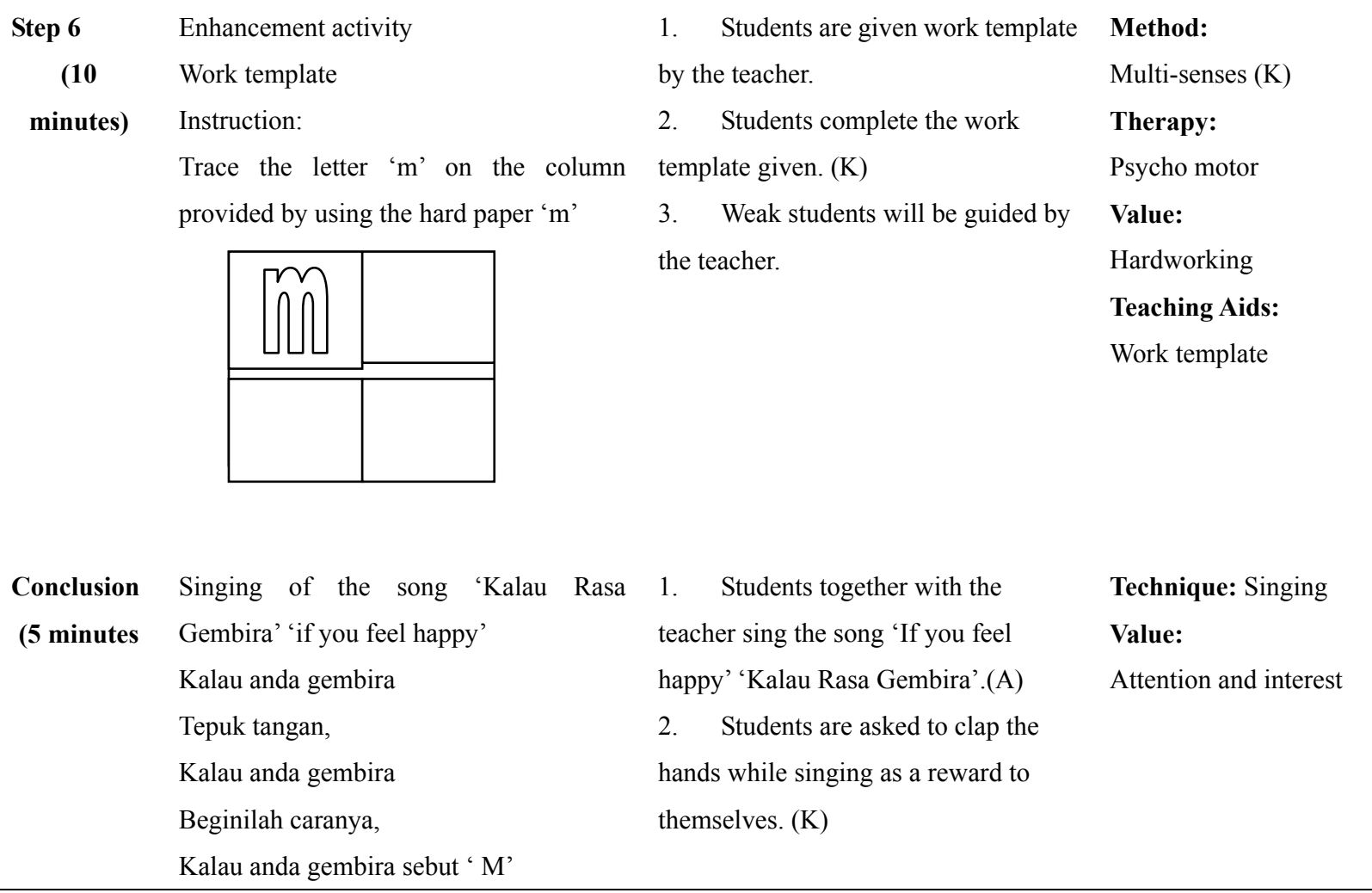

Multi-Senses Explication Activity 4

\begin{tabular}{|c|c|c|}
\hline Subject & $:$ & Malay Language \\
\hline Date & $:$ & \\
\hline Time & : & 60 Minutes (1 hour) \\
\hline No. of Students & : & \\
\hline Title & : & Body parts 'w' \\
\hline Skill & : & 6.2 Identify, trace, copy forms of letter, syllable and words. \\
\hline Combination of Skills & : & $\begin{array}{l}\text { 5.3.1 Exercising on eyes and hands coordination while writing. } \\
\text { 1.11 Moving of hands, wrists and fingers. }\end{array}$ \\
\hline Learning Outcome & : & $\begin{array}{l}\text { At the end of the lesson, students will be able to:- } \\
\text { 1. Pronounce the letter 'w' with correct pitch and intonation in front of the mirror. } \\
\text { 2. Name the letter 'w' by using visual card. } \\
\text { 3. Shape the letter 'w' with a straw. } \\
\text { 4. Write and sketch 'w' by using sand. } \\
\text { 5. Copy the letter 'w' and form a 'w' formation. }\end{array}$ \\
\hline Method & $:$ & Multi-senses \\
\hline Across Curriculum & : & Science, Arts, Community research \\
\hline Value Absorbed & $:$ & Cooperation, Self confidence, Listen to instructions, Patience \\
\hline Therapy Elements & $:$ & Speaking, Touching, Work Ethics, Focus. \\
\hline Teaching Aids & : & Video, letter card, straw, fishing set, colour paper, glue and drawing block. \\
\hline
\end{tabular}




\begin{tabular}{|c|c|c|c|}
\hline Step & Content & Teaching and Learning Activities & Remarks \\
\hline \multirow{11}{*}{$\begin{array}{l}\text { Set } \\
\text { Induction } \\
\text { (5 minutes) }\end{array}$} & Video recording & 1. Students are showed video on kite & Method: \\
\hline & \multirow[t]{8}{*}{ Kite flying competition } & flying on the field. (V-A). & Multi-senses $(\mathrm{V}, \mathrm{A})$ \\
\hline & & 2. Teacher is asking and answering & Therapy: \\
\hline & & questions with the students. (A) & Speech \\
\hline & & 3. Teaher explained on the title for & Value: \\
\hline & & today's lesson has got to do with the letter & Cooperation, \\
\hline & & 'w'(A). & confidence \\
\hline & & & Teaching Aids: \\
\hline & & & Kite, video \\
\hline & \multicolumn{3}{|l|}{ Answer: } \\
\hline & \multicolumn{3}{|l|}{ Kite } \\
\hline \multirow{9}{*}{$\begin{array}{l}\text { Step } 1 \\
\text { (6 minutes) }\end{array}$} & \multirow{9}{*}{ Introduce the letter ' $w$ ' } & 1. Students are asked to find green & Method: \\
\hline & & envelope. (V-K) & Multi-senses $(\mathrm{K}, \mathrm{A})$ \\
\hline & & 2. Students must take the envelope. & Therapy: \\
\hline & & & Speech \\
\hline & & 3. Students are asked to open up and & Value: \\
\hline & & take out the letter inside the envelope. & Cooperation \\
\hline & & $(\mathrm{K})$. & Teaching Aids: \\
\hline & & 4. Students are asked to say the letter & Mirror, visual card 'w', \\
\hline & & in front of the mirror. (A-V) & green envelope \\
\hline \multirow{9}{*}{$\begin{array}{l}\text { Step } 2 \\
\text { (6 minutes) }\end{array}$} & \multirow{6}{*}{$\begin{array}{l}\text { Form letter ' } w \text { ' by using the straw } \\
\text { (Straw) }\end{array}$} & 1. Teacher gives explanation and & Method: \\
\hline & & guidance to students to form the letter ' $\mathrm{w}$ ' & Multi-senses (V, K,A, T) \\
\hline & & by using the straw. (V-A) & Therapy: \\
\hline & & 2. Each student is given four pieces of & Soft motor \\
\hline & & straws. & Value: \\
\hline & & 3. Then students must form the letter & Cooperation \\
\hline & \multirow[t]{3}{*}{ Before } & 'w' by using the straws. (K) & Teaching Aids: \\
\hline & & 4. After that, students are asked to surf & Straw \\
\hline & & & \\
\hline \multirow{9}{*}{$\begin{array}{l}\text { Step } 3 \\
\text { (8 minutes) }\end{array}$} & \multirow{5}{*}{$\begin{array}{l}\text { Sketching the 'w' letter by using sand } \\
\text { in the plater }\end{array}$} & 1. Students are asked to watch the & Method: \\
\hline & & teacher sketching the letter ' $w$ ' on the & Multi-senses (V, K,A) \\
\hline & & surface of the sand. (V) & Therapy: \\
\hline & & 2. Students are then asked to sketch & Soft motor, observation \\
\hline & & the letter ' $w$ ' on the surface of the sand & Value: \\
\hline & Before & repeatedly. (K) & Hardworking, listen to \\
\hline & & 3. Students are asked to say the letter & instructions, patience \\
\hline & & ' $w$ ' individually and together as a whole & Teaching Aids: \\
\hline & & class. (A) & Sand \\
\hline
\end{tabular}



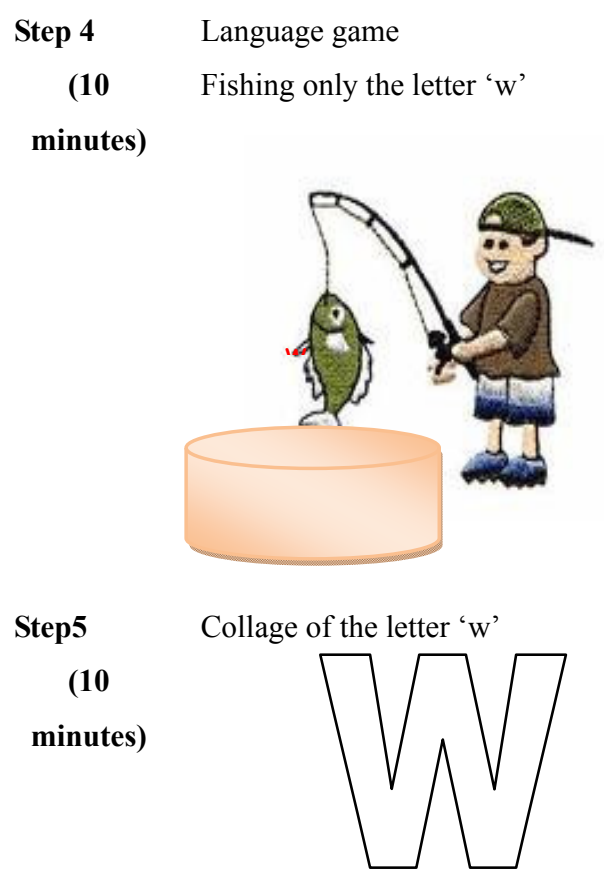

Before

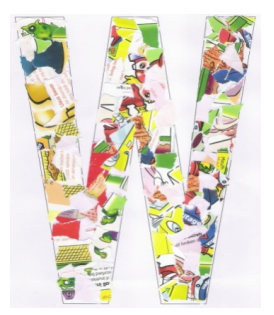

After
1. Teacher shows a set of letter fishing to the students. (V)

2. Students chosen by the teacher will have to fish the letter ' $w$ ' only. (K)

3. Other students are asked to say the letter caught by the friends. (A)

4. The activity has to be repeated until all students manage to fish all the ' $w$ ' letter. (K)

5. Weak students will be guided by the teacher.

1. Students are given a fe pieces of color papers by the teacher.

2. Students ae aksed to tear the color papers until they get small pieces of papers. (K)

3. Students are asked to paste the pieces of papers onto the surface of the big letter ' $w$ '. (K-T)

4. Students are asked to say the letter together. (A)

5. Students are given assessment on their work after everything finishes.

6. Students are successful are given a big round of applause.



1. Students must say the letter ' $w$ ' repeatedly while doing the body formation for the shape of 'w. (A-K)

2. Teacher is summarizing the content by having the Q\&A session with the students. (A)

\section{Method:}

Multi-senses (V, K,A)

drilling

\section{Therapy:}

Soft motor, observation

Value:

Cooperation

Teaching Aids:

Fishing set

\section{Method:}

Multi-senses

drilling

\section{Therapy:}

Soft motor

Value:

Hardworking, patience

Teaching Aids:

Work template, pieces of papers

\section{Therapy:}

Speech

Value:

Listen to instructions

\section{Multi-Senses Explication Activity 5}

\begin{tabular}{lll}
\hline Subject & $:$ & Malay Language \\
\hline Date & $:$ & \\
Time & $:$ & 60 Minutes (1 hour) \\
No. of Students & $:$ & \\
Title & $:$ & Fruits 'n' \\
Skill & $:$ & 3.3 Vowel and consonant forms and sounds. \\
Combination $\quad$ of & & 5.3 .1 Exercising on eyes and hands coordination while writing. \\
Skills & $:$ & 5.1 .1 Moving of hands, wrists and fingers.
\end{tabular}


Learning Outcome : At the end of the lesson, students will be able to:-

1. Pronounce the letter ' $n$ ' with correct pitch and intonation in front of the mirror.

2. Connect letter ' $n$ ' with a rope and ' $n$ ' shape card.

3. Identify the letter ' $n$ ' only.

4. Shape the ' $n$ ' letter in the language game activity.

5. Match picture with letter ' $n$ '.

Method

Across Curriculum

Value Absorbed

Therapy Elements

Teaching Aids
: Multi-senses

: Science, Arts, Physical education

: Cooperation, Self confidence, Listen to instructions, Patience, Hardworking, Clean and Healthy lifestyle

: Soft and hard motor and colours.

: Picture card, letter card, cone, jigsaw puzzle, wire, laptop, work template.

\begin{tabular}{ll}
\hline \multicolumn{1}{c}{ Step } & \multicolumn{1}{c}{ Content } \\
\hline Set & Mystery box \\
Induction & Real object \\
(5 minutes) & jack fruit \\
\cline { 2 - 3 } & \\
&
\end{tabular}

Step 1

Use the visual card

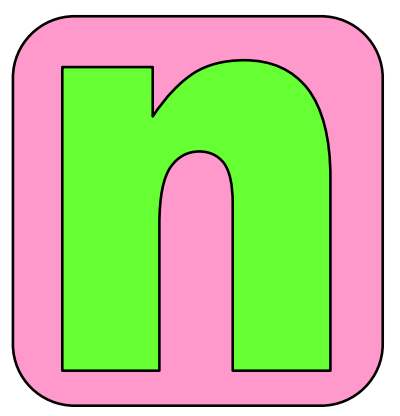

Step 2

(6 minutes)
Introduce fruits that begins with letter ' $n$ '

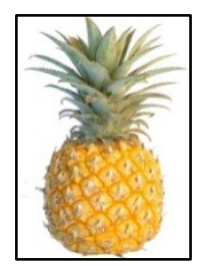

Teaching and Learning Activities

1. Teacher shows the mystery box that has the jack fruit.

2. Students are asked to listen to clues given by the teacher. (A)

Remarks

Method:

Multi-senses

$(\mathrm{A}, \mathrm{T})$ drilling

Therapy:

3. Then, the students are given opportunity to touch Music the fruits and guess what it is. $(\mathrm{T})$. Value:

4. Teacher connects the fruit with the title of the Healthy lessob- letter ' $n$ '.

lifestyle

Teaching Aids:

Laptop

1. Students are asked to see the letter ' $n$ ' pasted on the Method: whiteboard. (V)

Multi-senses

2. Students are asked to listen carefully to the letter ' $n$ ' (V, A, K, T) said by the teacher. (A)

Therapy:

3. Students are asked to say the letter ' $n$ ' individually. Soft motor (A)

Value:

4. Students are to touch and feel the letter. (T)

Listen to

5. Students are to move the muscles by sketching the instructions, letter ' $n$ ' in the air. $(\mathrm{K})$ cooperation

Teaching Aids: Visual card of ' $\mathrm{n}$ '

1. Students are given an envelope that has pictures of Method: pineapple, jack fruit and custard apple.

Multi-senses

2. Students pasted the pictures on the whiteboard. (K) $(\mathrm{K}, \mathrm{A})$

3. Students guess the names of the fruit in the picture. Therapy: (A)

Colour

4. Teacher connects the picture with the letter ' $n$ '

Value:

5. Students must listen to the pronunciation of the 
Nanas/pineapple



Nangka/jack fruit

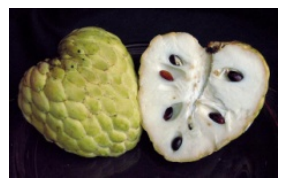

Nona/custard apple

Step 3

(8 minutes)

Connect the letter ' $n$ '
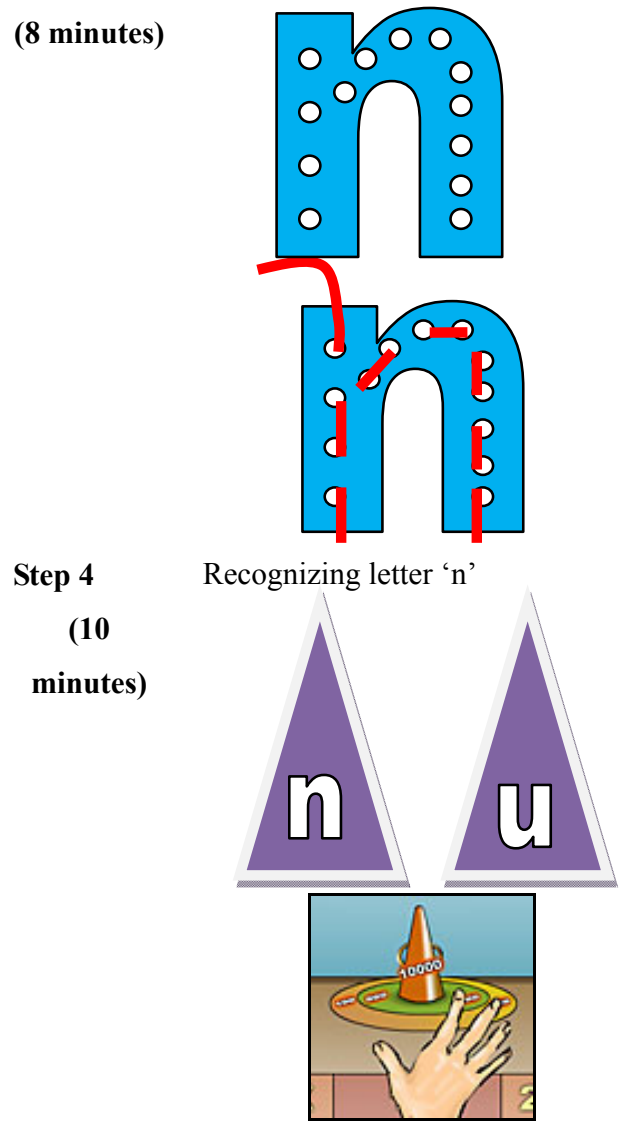

Step5 Language game

(10 "Let's ride on the train"

minutes)

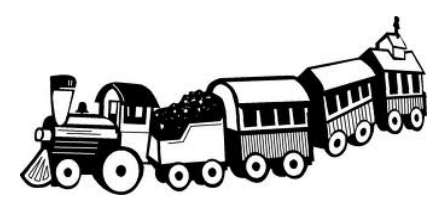

letter ' $n$ ' by the teacher. (A)

lifestyle, self

6. Students must sketch the letter ' $n$ ' on the surface of confidence the sand while saying the letter ' $n$ '. (K- A)

Teaching Aids:

Picture, letter card

1. Students are given the letter card ' $n$ ' that has a hole Method: on the card.

Multi-senses

2. Students are given a piece of rope each.

$(\mathrm{K}, \mathrm{T}, \mathrm{A})$

3. Students connect the letter ' $n$ ' and put in the rope into the holes of the card. (K).

Therapy:

Soft motor

4. Students touch the surface and say the letter ' $n$ '

Value: correctly. (T-A).

Self

confidence

Teaching Aids:

Letter card,

rope

Aktivity 1:

Method:

1. Teacher puts two cones marked ' $n$ ' and ' $u$ '

Multi-senses

2. Students queue in front of the cones with a two-step $(\mathrm{K}, \mathrm{V})$ distance from each other. $(\mathrm{K})$

Therapy:

3. Students are given three coils to be thrown at the ' $n$ ' Hard motor mark. (K)

Value:

4. Teacher moves the two cones so that the student could recognise the letter ' $n$ '. (V)

Patience

Teaching Aids:

Cone, glue, letter card ' $\mathrm{n}$ ' and ' $\mathrm{u}$ '

1. Students are introduced to the rules of the game.

Method:

2. Teacher begins the simulation activity with the 'Let's ride on the train'

Multi-senses

$(\mathrm{V}, \mathrm{K}, \mathrm{A})$

3. Teacher asks students to queue separately male and female facing the whiteboard like trains.

Therapy:

Speech

4. Each student is asked to write the letter ' $n$ ' at the

Value: back of their friends by using the index fingers and saying the letter ' $n$ '.

Careful and cooperation

5. Teacher asks students to turn around and face the teacher and repeat the activity. 


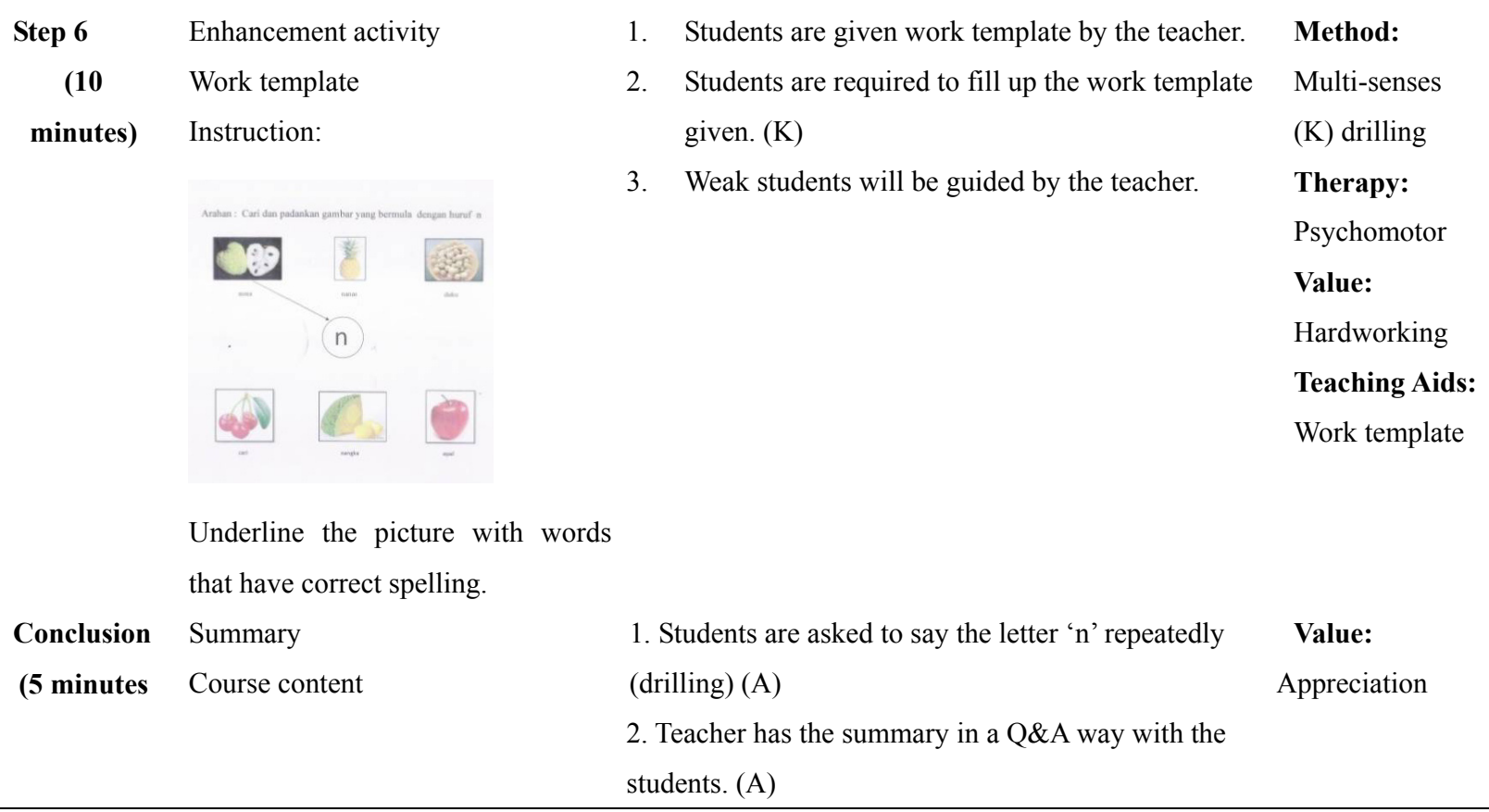

\section{Multi-Senses Explication Activity 6}

\begin{tabular}{|c|c|c|}
\hline Subject & : & Malay Language \\
\hline Date & $:$ & \\
\hline Time & $:$ & 60 Minutes (1 hour) \\
\hline No. of Students & $:$ & \\
\hline Title & : & Letter ' $u$ ' \\
\hline Skill & : & 5.3 Forming eyes and hands coordination. \\
\hline Combination of & & 6.1 Identify, trace, copy letter forms, syllable and word \\
\hline Skills & : & 5.3.1 Exercising on eyes and hands coordination while writing. \\
\hline & & 3.3.1 Forming the forms and sounds of consonants and vowels. \\
\hline \multirow[t]{7}{*}{ Learning Outcome } & : & At the end of the lesson, students will be able to:- \\
\hline & & 1. Identify the letter ' $u$ ' based on the visual card. \\
\hline & & 2. Pronounce the letter ' $u$ ' with correct pitch and intonation. \\
\hline & & 3. Sketching the letter ' $u$ ' on the surface of the carpet while playing with the letter. \\
\hline & & 4. Write by connecting the dots to form the ' $u$ ' letter. \\
\hline & & 5. Form the jumping ' $u$ ' shape exercise. \\
\hline & & 6. Form the letter ' $u$ ' by using the wire. \\
\hline Method & : & Multi-senses \\
\hline Across Curriculum & : & Science, Arts, Mathematics \\
\hline Value Absorbed & : & Cooperation, Self confidence, Listen to instructions, Patience \\
\hline Therapy Elements & $:$ & Speaking, Touching, Work Ethics, Focus. \\
\hline Teaching Aids & $:$ & $\begin{array}{l}\text { Animation video, picture card, visual card, carpet, wire, hard paper, wheel of fortune set, work } \\
\text { template and skipping rope. }\end{array}$ \\
\hline
\end{tabular}




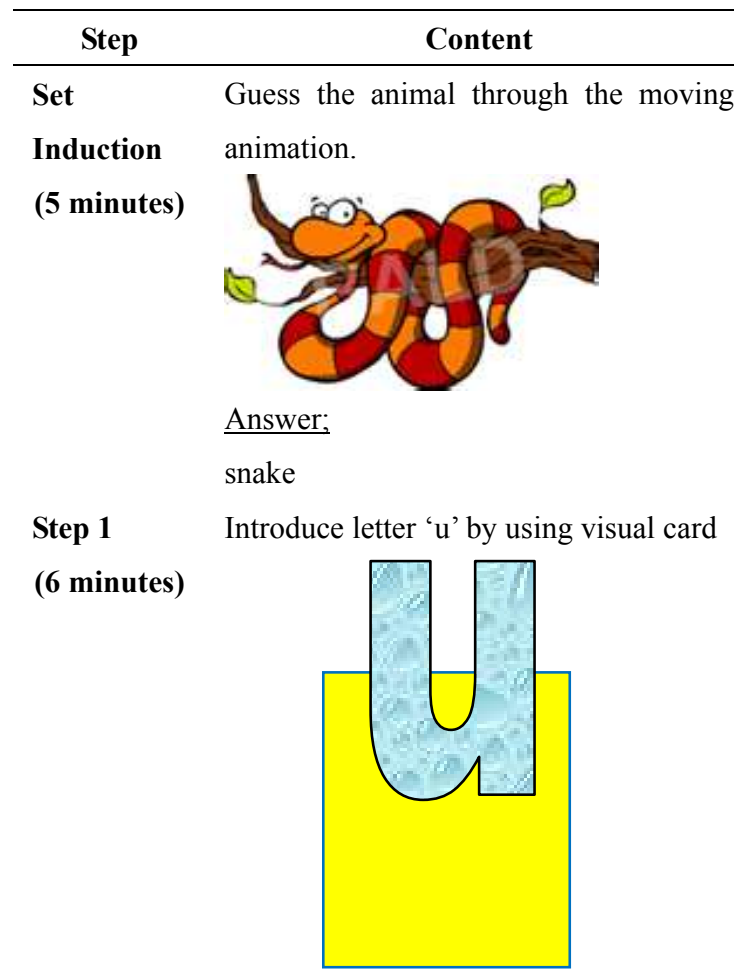

Step 2

(6 minutes)

Sketch the letter ' $u$ ' by using rough

surface like carpet

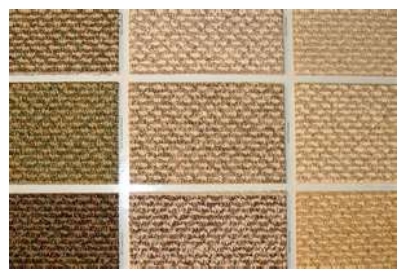

Step 3 Shape the letter ' $u$ ' with he stretchable (8 minutes) wire

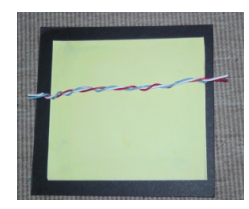

Before

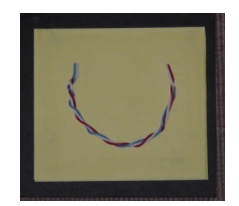

After

Step 4 Name the animal in the photo that begins

(10 minutes)
Teaching and Learning Activities

Remarks

1. Students are showed with animation picture of moving animal. (V)

2. Students guess what animal is showed to them. (A)

3. Teacher connect the animal showed with the title of today's lesson- letter ' $u$ '.

1. Students are showed visual card with the letter ' $u$ '. (V).

2. Students must see the letter ' $u$ ' carefully especially its form. (V)

3. Students say the letter ' $u$ ' repeatedly in front of the mirror. (A)

1. Teacher asks students to raise their hands and index finger. $(\mathrm{K})$

2. Students must pur the fingers on the surface of the carpet to sketch the letter ' $\mathrm{u}$ '. (T-K)

3. Perform activity like step 2 over and over again.

1. Students are given a piece of wire.

2. Teacher shows students on the process to shape the wire to the letter ' $u$ '. (V)

3. Students must shape the wire to the letter ' $u$ '. (K)

4. Students must say the letter ' $u$. (A)

1. Students must recognise the photo given by the teacher. $(\mathrm{V})$

2. Students must name the animals (prawn, snake, camel, and worm). (A)

3. Teacher connects the picture with the animals that begin with the letter ' $u$ '.

\section{Method:}

Multi-senses (V, A)

Therapy:

Speech and focus

Value:

Listen to instructions

Teaching Aids:

Powerpoint slides

Method:

Multi-senses (V, A)

Therapy:

Speech

Value:

Cooperation

Teaching Aids:

Object picture, visual card letter ' $u$ '

Method:

Multi-senses $(\mathrm{K}, \mathrm{T})$

Therapy:

Value:

Listen to instructions

Teaching Aids:

carpet

Method:

Multi-senses

(V,

$\mathrm{K}, \mathrm{A}$ )

Therapy:

Soft motor

Value:

Listen to instructions

Teaching Aids:

Wire, hard paper

Method:

Multi-senses

$(\mathrm{V}$,

$\mathrm{K}, \mathrm{A}$ ) drilling

Therapy:

Observation, way of working 


\section{Ular/snake}
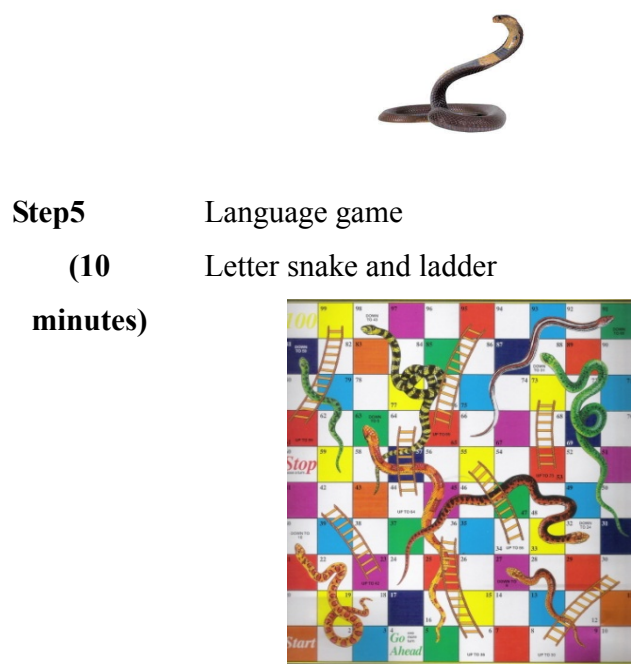

Snake and ladder set

\section{Step 6 Enhancement activity \\ (10 Work template \\ minutes) Instruction: Template 1}

Connect the dots to form the ' $u$ ' shape

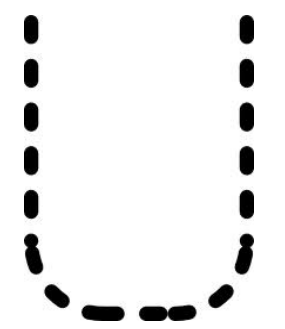

Conclusion Jumping in ' $u$ ' shape

(5 minutes

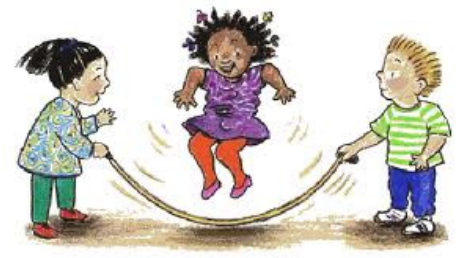

4. Students are asked to choose a

picture to sketch on the drawing block. $(\mathrm{K})$

5. Then students are asked to colour the picture and the letter. $(\mathrm{K})$

1. Students are introduce to the set of snake and ladder game and are given instructions on how to play it. (A)

2. Students are required to throw the dice. The dice has two surfaces that show 2 letters of ' $u$ ' and 2 letters of ' $n$ '. (K)

3. Students are given opportunity to throw thrice the dice in every turn. (K)

4. To the successful students wo mange to get the ' $u$ ' letter, they can move forward. But if they fail they can only move a step forward. (K)

1. Students are given a work template. Students need to connect the dots to form the ' $u$ ' shape.(k)

2. Students are asked to say the letter ' $u$ ' with correct intonation. (A)

3. Teacher pastes students' work and gives them compliment if they manage to finish the task.

1. Two students hold a rope in a ' $u$ ' shape.

2. Other students jump while saying the letter ' $u$ ' repeatedly.

3. Students take turn in holding the rope and jumping.
Value:

Cooperation

\section{Teaching Aids:}

Visual paper letter ' $u$ ' and picture card

Method:

Multi-senses (K,A)

\section{Therapy:}

Observation, way of working

Value:

Listen to instructions

\section{Teaching Aids:}

Snake and ladder set and dice

\section{Method:}

Multi-senses (V,A)

\section{Therapy:}

Soft motor

Value:

Hardworking, Listen

to instructions

\section{Teaching Aids:}

Work template

\section{Method:}

Exercise jumping in 'u' shape

Therapy:

Hard motor, speech

Value:

Hardworking, Listen to instructions, cooperation

Teaching Aids:

Skipping rope 
Multi-Senses Explication Activity 7

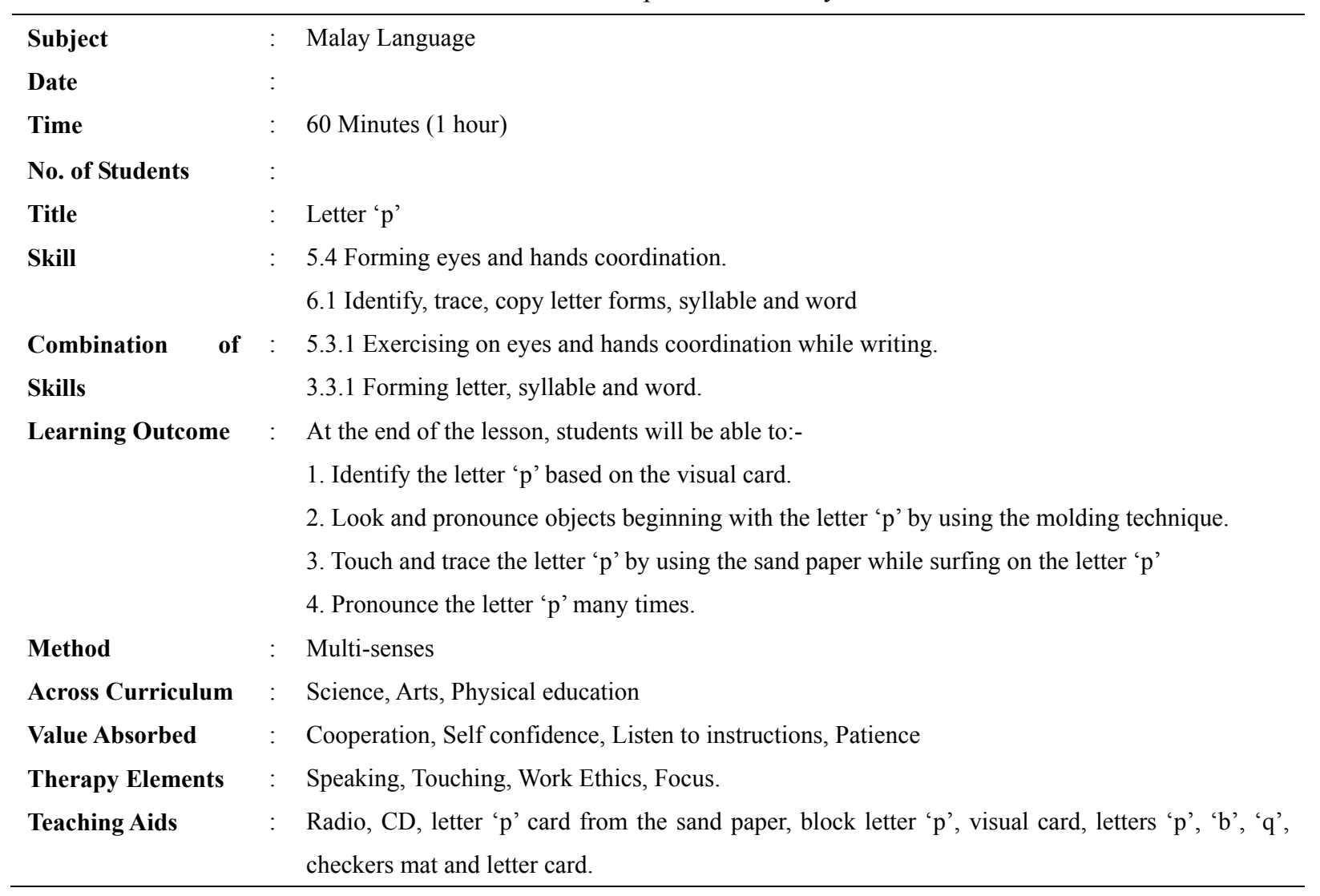

\begin{tabular}{ll}
\hline \multicolumn{1}{c}{ Step } & \multicolumn{1}{c}{ Content } \\
\hline Set & Singing \\
Induction & Lyrics (in Malay): \\
(5 minutes) & Papaku pulang dari kota. \\
& Papaku belikan kereta. \\
& Kereta kecil warna biru. \\
& Bolehku bawa ke sekolah \\
Step 1 &
\end{tabular}

Picture of objects that begin with 'p' like pen, pencil, ruler and eraser

\section{Teaching and Learning Activities Remarks}

1. Students are to listen to the song "My Method: Father came back from Town" (A) Multi-senses (K,A)

2. Students must sing the song properly. Therapy:

3. Students and teacher sing the song with Speech background music while moving their Value: body. (K-A) Listen to

4. Teacher relates the song with the lesson instructions for today. Teaching Aids:

Radio and CD

1. Students are showed the visual card that Method: has letter 'p' on the white board. (V) Multi-senses

2. Students say the letter ' $p$ ' over and over Therapy: again. (A) Speech

3. Students are showed picture of Value: stationery that begins with the letter ' $p$ '. Cooperation (V).

Teaching Aids:

4. Students say the object (pen, pencil, Picture card, visual ruler and eraser) (A) letter 'p' card 


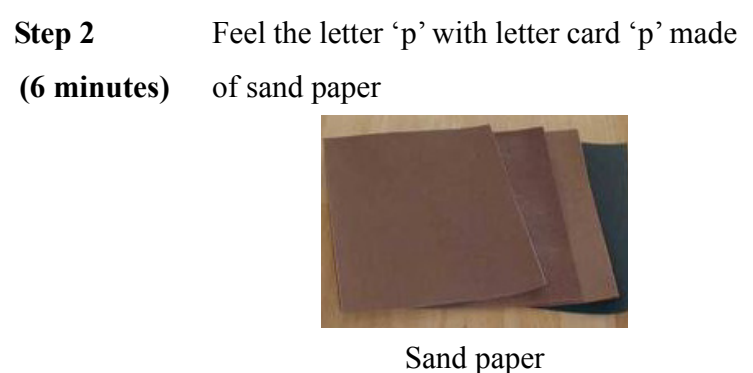

Step 3

(8 minutes)

Form letter 'p' with molding technique

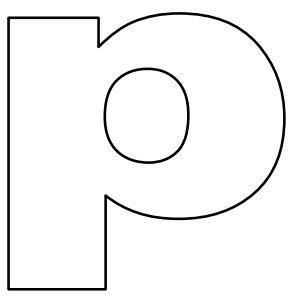

Letter 'p' mold plate

Step 4 Recognise the letter ' $p$ ' and choose the

(10

minutes)

letter 'p' card

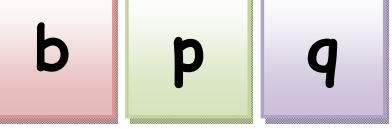

Paste the letter 'p' on the whiteboard

$\begin{aligned} \text { Step5 } & \text { Language game } \\ (\mathbf{1 0} & \text { Letter checkers }\end{aligned}$

minutes)
1. Teacher distributes the letter ' $p$ ' card made of sand paper.

2. Students are to feel the letter ' $p$ ' with their index finger repeatedly. (T-K)

3. Students are to pronounce the letter ' $p$ ' Soft motor as a drilling exercise..(A)

Value:

Listen

instructions

Teaching Aids:

Letter 'p' card, sand paper

1. Students are given a mold paper each.

2. Teacher shows the process of how to form the letter 'p' with the mold paper.Guru membuat tunjuk cara kep (V)

\section{Method:}

Multi-senses

Therapy:

Soft motor

Value:

3. Students must sketch the letter ' $p$ ' Listen to repeatedly by using the mold plate. (T) instructions

4. Students are required to say the letter together. (A)

Teaching Aids:

Molding letter ' $\mathrm{p}$ ' card

1. Students are showed visual cards of letters ' $b$ ', ' $p$ ' and ' $q$ ' that are put randomly on the table. (V)

Multi-senses

Therapy:

2. Students are asked to choose which is Observation letter 'p' and paste it on the whiteboard, Value: one by one. $(\mathrm{K})$

Cooperation

Teaching Aids:

Visual letter 'b', 'p'. ' $q$ ' card

1. Teacher puts letter ' $p$ ' and other other letter ' $b$ ', ' $d$ ' and ' $q$ ' on the checkers

Method: mat.

Language game, letter checkers

2. Students are to recognise the letter ' $p$ '. Therapy: (V)

Observation

3. Students are to aim the throwing of the (checkers) bullet to the place has letter 'p' only until they succeed. (K)

techniques

4. Students hold the letter ' $p$ ' that they get Listen and say the letter 'p' for three times. (A) instructions

Teaching Aids:

Letter card, checkers mat 


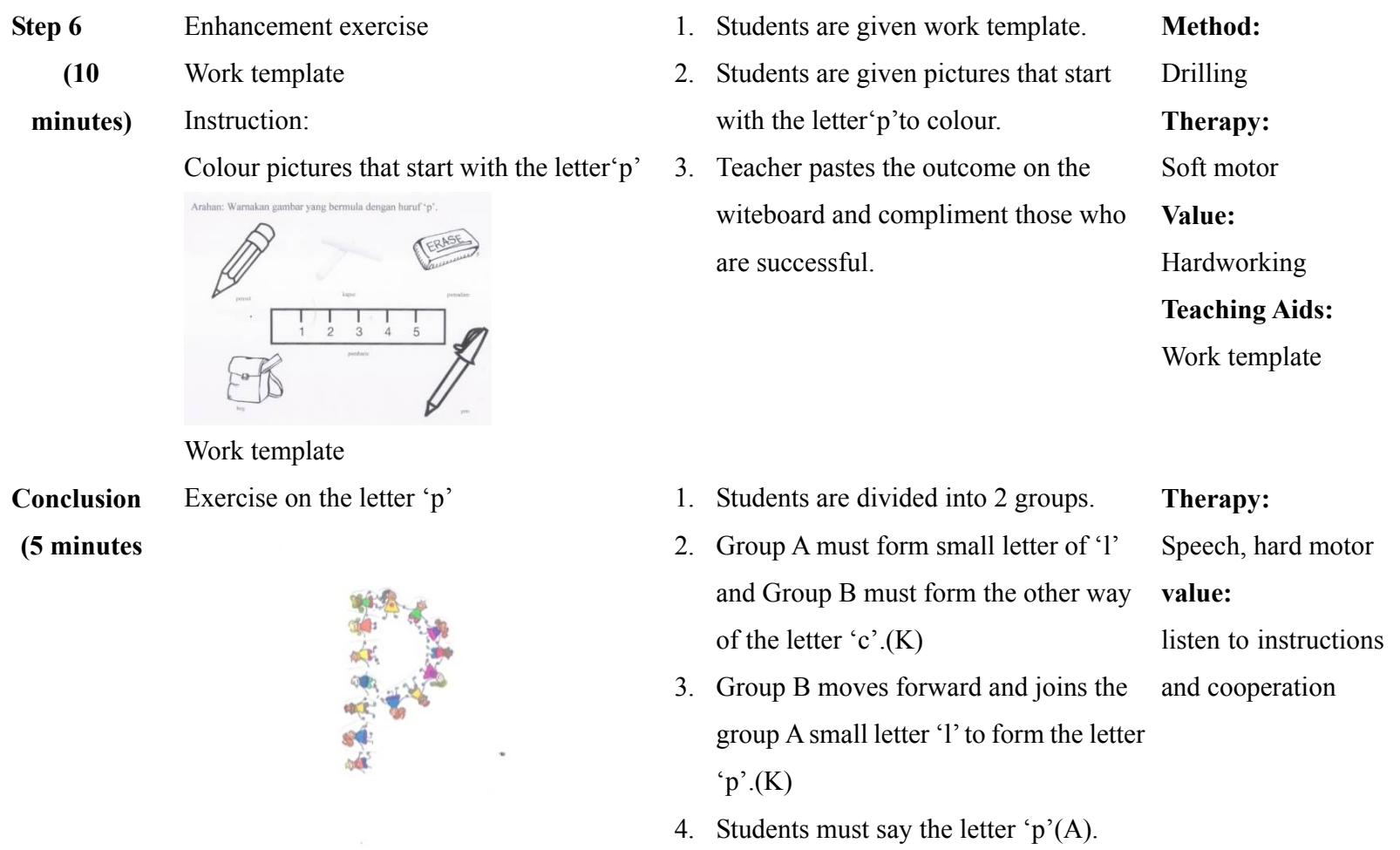

Multi-Senses Explication Activity 8

\begin{tabular}{|c|c|c|}
\hline Subject & $:$ & Malay Language \\
\hline Date & : & \\
\hline Time & $:$ & 60 Minutes ( 1 hour) \\
\hline No. of Students & $:$ & \\
\hline Title & : & Letter ' q' \\
\hline Skill & : & $\begin{array}{l}\text { 5.4 Forming eyes and hands coordination. } \\
6.1 \text { Identify, trace, copy letter forms, syllable and word }\end{array}$ \\
\hline $\begin{array}{l}\text { Combination of } \\
\text { Skills }\end{array}$ & $:$ & $\begin{array}{l}\text { 5.3.1 Exercising on eyes and hands coordination while writing. } \\
\text { 3.3.1 Forming letter, syllable and word. }\end{array}$ \\
\hline Learning Outcome & $:$ & $\begin{array}{l}\text { At the end of the lesson, students will be able to:- } \\
\text { 1. Pronounce the letter ' } q \text { ' with the correct pitch and intonation together with the whole class. } \\
\text { 2. Trace and write the letter ' } q \text { ' by using flour. } \\
\text { 3. Trace and draw the letter ' } q \text { ' correctly. } \\
\text { 4. Categorise the letter ' } q \text { ' correctly. }\end{array}$ \\
\hline Method & $:$ & Multi-senses \\
\hline Across Curriculum & $:$ & Science, Arts, Mathematics \\
\hline Value Absorbed & $:$ & Cooperation, Self confidence, Listen to instructions, Patience, Hardworking \\
\hline Therapy Elements & : & Speech, listening, seeing and psychomotor therapy. \\
\hline Teaching Aids & $:$ & $\begin{array}{l}\text { Letter card, mystery box, letter 'q' card, rope, hard paper, coloured rice, pieces of papers, drawing } \\
\text { block and glue. }\end{array}$ \\
\hline
\end{tabular}




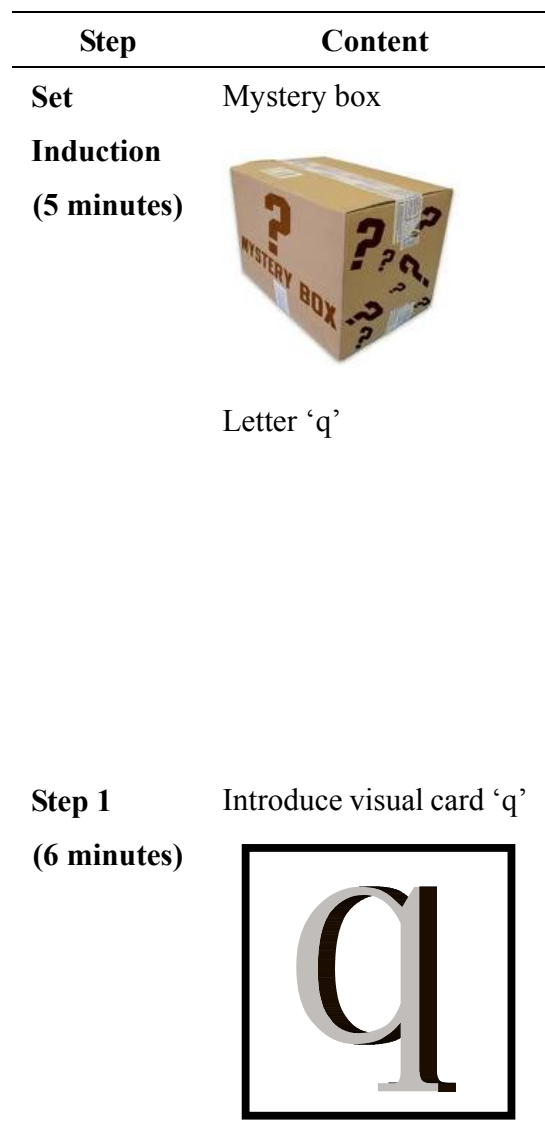

Step 2

(6 minutes)

Feel the letter 'q' with

rope letter card

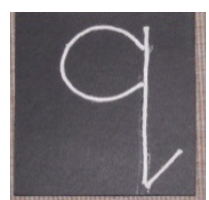

1. Teacher shows the mystery box to the students. In the mystery Method: box, there letters and Al-Quran. (V)

Multi-senses (V,

2. Students are given clues. (A)

3. Students are asked to guess what is inside the mystery box.

A,)

4. Students guess and give answers. (A)

Therapy:

5. Teacher relates the answers with today's lesson.

Listening and

observation

Value:

Cooperation,

caring and

interest

Teaching Aids:

Mystery box, Al

Quran

Method:

2. Students are to listen to the teacher saying the letter carefully.

(A)

Multi-senses (V,

A,)

3. Students are required to say the letter ' $q$ ' showed by the teacher. Therapy:

(A)

4. Individually, students must say the letter ' $q$ ' repeatedly. (A)
Speech and psychomotor

Value:

Hardworking,

caring and

interest

Teaching Aids:

Visual letter card

Method:

Multi-senses (V, $\mathrm{K}, \mathrm{T}, \mathrm{A}$,)

Therapy:

3. Students are to feel the card that is made of rope. (T)

4. Students are to surf their index finger to form a letter ' $q$ '. (K-T) Speech, listen

5. Students are to say the letter ' $q$ ' together. (A) and soft motor

Value:

Hardworking, caring, listening and interest

Teaching Aids:

Letter ' $q$ ' made of rope 
Step 3 Language game to 1. Teacher explains the game. (A)

(8 minutes) categorise the letter ' $\mathrm{q}$ ' Butterfly picture

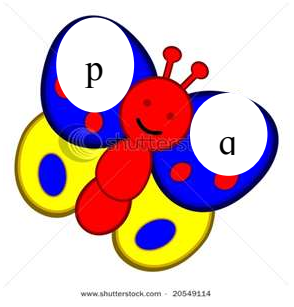

Before

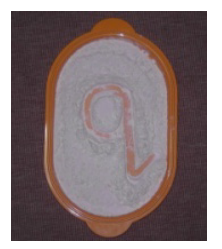

After


left wings of the butterfly. (K)

3. Teacher starts the music and box that has the letter is distributed to the students. (A-K).

4. Students hold the box and as the music stops, the student who has the box will pick up a letter and paste the letter onto the wings. (K)

1. Teacher shows the letter ' $q$ ' to the students. (V)

2. Teacher distributes the plate that has flour to the students.

3. Students are asjed to sketch the letter ' $q$ ' on the surface of the flour by using the index finger. (K-T)

4. Students say the letter ' $q$ ' while sketching. (A-T)
2. Students are required to paste the letter ' $q$ ' onto the right and

\section{Method:}

Multi-senses

(K, A)

\section{Therapy:}

Psychomotor,

focus

Value:

Hardworking, caring, listening and interest

Teaching Aids :

Box, letter ' $q$ ' and

'p', game

Method:

Multi-senses (V,

T, K, A)

Therapy:

Psychomotor,

soft motor

Value:

Hardworking, caring, listening and self confidence

Teaching Aids :

Flour, plate and sponge letter

Method:

Step5 Trace amd draw the 1. Teacher distributes the letter ' $\mathrm{q}$ ' to the students.

(10 letter 'q'

2. Students must trace the letter ' $\mathrm{q}$ ' onto the box provided. $(\mathrm{K})$

minutes)

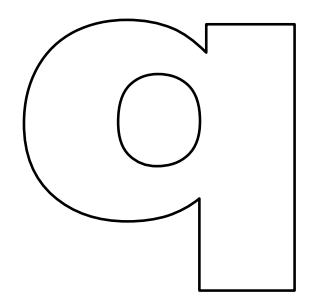

3. Students must draw and form the letter ' $\mathrm{q}$ ' repeatedly. (K-T)

4. Students must write the letter ' $\mathrm{q}$ ' onto the sirface of the drawing block. (K)

5. Teacher pastes the outcome of the students' work on the whiteboard and gives star to the deserving ones.
Multi-senses (T,

$\mathrm{K}, \mathrm{A})$

Therapy:

Observation

Value:

caring, cooperation, interest

Teaching Aids :

Work template 'q' 


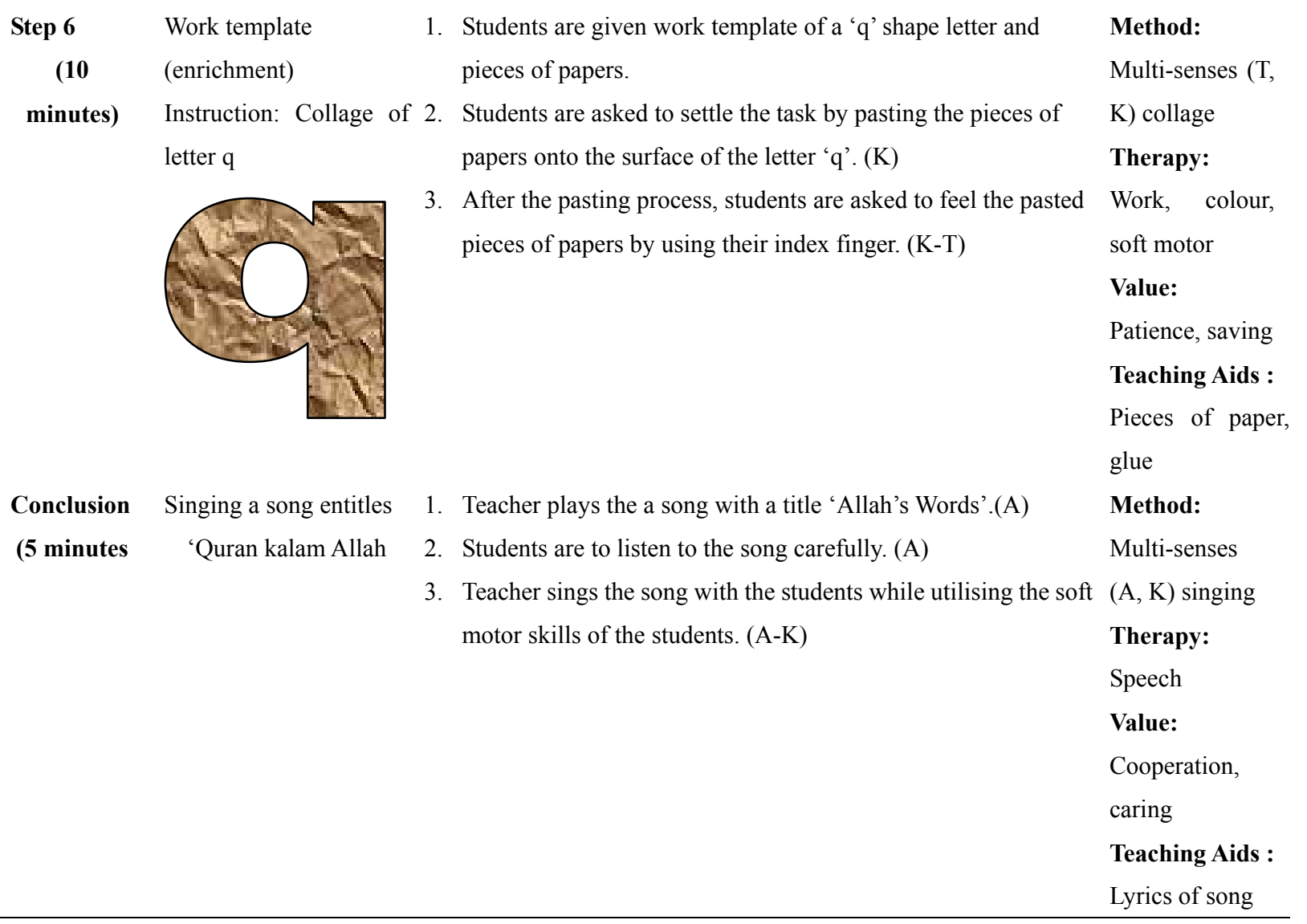

\section{Conclusion}

The children can learn effectively if they experience the learning process directly by themselves. A Chines idiom (in Feldman 1991) used to say "I listen and I forget, I see and I do and I understand". The learning process can be more meaningful and effective when the dyslexia children can apply all their senses. Each and every sense is a path or bridge in their brain. The more paths or bridges in the brain, the better the learning that happens. Learning through senses emphasizes on the needs of the multi-senses and materials that can trigger the dyslexia children senses.Based on the interview between researcher and the coordinator of the programme and dyslexia children, we could see that the learning module produced was based on the multi-senses explication activities. They are auditory, visual, tactic and kinetic that give guidance to the teachers in providing the learning mode in the Malay language that is suitable with the dyslexia children needs. In addition, the playing element absorbed in the fun and creative language game could attract the children's attention and highlighting active learning environemnt for the children to have fun in learning. Therefore, researcher thinks that in improving the performance and behavior of the dyslexia children in mastering the words reading, determing the similar letter concept to avoid confusing should be strengthen. After this stage, then only teachers could teach words syllable and followed by sentence once the children have mastered the previous stage.

\section{References}

Ahmad, N. (2005). 350,000 murid sekolah rendah alami disleksia. Utusan Malaysia, 17.

Ali, M. M. (2005). Phonological of Malaysian blingual children. Malaysian Journal of ELT Research. Retrieved February 14, 2009, from http://www.melta.org.my/modules/tinycontent/Dos/manisah_melta_journal_2005.pdf

Devaraj, S., \& Roslan, S. (2006). Apa itu, Disleksia? Panduan Untuk ibu bapa dan Kaunselor. Kuala Lumpur: PTS Profesional.

Gagne, R. M. (1975). Essential of Learning for Instruction. NJ: Prentice-Hall.

Idham, M., Mahamod, Z., Yunus, M. M., \& Yusoff, N. M. R. N. (2010). Profil Kecerdasan Emosi Guru Pelatih Bahasa Mengikut Tahun Pengajian. GEMA Online ${ }^{T M}$ Journal of Language Studies, 10(2), 57-75. 
Irwin, G. (2000). Dyslexia. Manila BSM SEN Conference.

Johan, J. (2005). Kementerian rujuk aduan masih banyak pelajar gagal menguasai 3M. Utusan Malaysia.

Kassim, M. (2003). Tinjauan Ciri-ciri Disleksia Di Kalangan Murid Pemulihan. Projek Sarjana pendidikan, Universiti Kebangsaan Malaysia, Malaysia.

Kementerian Pelajaran Malaysia. (2003). ISD Instrument Senarai Semak Disleksia: Manual. Jabatan Pendididkan Khas Kementerian Pelajaran Malaysia.

Komala, P. D. (2004). Disleksia - Ramai Kanak-kanak tidak kenal huruf. Utusan Malaysia.

Lie, K. Y., \& Azman, H. (2010). Tahap Literasi dalam Bahasa Inggeris di Kalangan Belia di Institut Belia Kebangsaan. GEMA Online ${ }^{T M}$ Journal of Language Studies, 10(1), 35-50.

Malek, H. (2001). Strategi Pengajaran Yang Boleh Digunakan Oleh Guru Khas Untuk Mengatasi Masalah Membaca Di Kalangan Kanak-kanak Disleksia. Projek Ilmiah. Universiti Kebangsaan, Bangi.

Mat, N. H. C. (2007). Masalah Pembelajaran Spesifik Disleksia dalam Kalangan Murid-murid Pemulihan Yang Mengikut Program Pemulihan Khas. Tesis Sarjana. Universiti Putra Malaysia. Serdang.

McCray, A. D., Vaughn, S., \& Neal, L. V. I. (2001). Not all students learn to read by third grade: Middle school students speak out about their reading disabilities. The Journal of Special Education, 35, 17-30. http://dx.doi.org/10.1177/002246690103500103

Mercer, C. D. (1997). Students UIT Learning Disabilities. U.S.A: Merrill, Prentice, Hall.

Mohamod, Z., \& Noor, N. A. M. (2011). Persepsi Guru Tentang Penggunaan Aplikasi Multimedia Dalam Pengajaran Kompenan Sastera Bahasa Melayu. GEMA Online ${ }^{T M}$ Journal of Language Studies, 11(3), 163-177.

Parman, N. H. (1997). Satu Kajian Mengenai Ciri-ciri Dyslexia di Kalangan Kanak-kanak Berumur 7 Hingga 9 Tahun. Projek Sarjana Muda, Universiti Kebangsaan Malaysia.

Persatuan Disleksia Wilayah Persekutuan. (2003). 10\% daripada kanak-kanak sekolah mengalami disleksia. Sin Chew Daily, 18.

Rafie, K. (2007). Tinjauan Ciri-ciri Disleksia dalam Kalangan Kanak-kanak KIA2M. Tesis Sarjana, Universiti Putra Malaysia, Serdang.

Shaywitz, S. T., Shawywitz, B. A., Pugh, K. R., Fulbright, R. K., \& Constable, R. T. (1998). Functional in organization of the brain for reading in dyslexia. Proceeding of National Academic Sciences, 95, 2636-2641. http://dx.doi.org/10.1073/pnas.95.5.2636

The International Dyslexia Association. (2010). Promoting Literacy Though Research, Education and Advocacy. Retrieved June 26, 2010, from http://www.interdys.org

Tonnessen, F. E. (1999). Options and limitation of the Cognitive Psychological Approach to the Treatment of Dyslexia. Journal of Learning Disabilities, 32(5), 386-393. http://dx.doi.org/10.1177/002221949903200504

Tressoldi, P. E., Vio, C., \& Lozzino, R. (2007). Efficacy of an intervention to improve fluency in children with developmental dyslexia in a regular orthography. Journal of Learning Disabilitie, 40(3), 203-209. http://dx.doi.org/10.1177/00222194070400030201

Ubaidullah, N. H. (2007). Perisian Kursus Multimedia dalam Literasi Matematik (D-Matematik) Untuk Pelajar Disleksia. Tesis Ph.D. Universiti Kebangsaan Malaysia, Bangi.

Umar, R. S., Rahman, F. A., Mokhtar, F., \& Alias, N. A. (2011). Menggunakan Animasi di dalam Instruksi Khas untuk Kanak-kanak Disleksia. Jurnal Teknologi Pendidikan Malaysia, 1(2), 27-38.

Wah, L. L. (2008). Pembinaan dan Pengesahan Ujian Bacaan Untuk Mengenal Pasti Masalah Disleksia. Tesis Ph. D. Universiti Kebangsaan Malaysia, Bangi.

Wahab, M. A. (2002). Tinjauan Ciri-ciri Disleksia Di Kalangan Murid Pemulihan Di Zon Pudu Persekutuan. Projek Sarjana Pendidikan, Universiti Kebangsaan Malaysia.

Yusof, N. A. M. (2006). Kerajaan perlu tambah program khas di sekolah. Berita Harian, 31.

Zaid, U. H. M. (2008). Masalah Ejaan Dalam Kalangan Murid-murid Bermasalah Pembelajaran Spesifik Disleksia. Tesis Sarjana. Universiti Putra Malaysia, Sedang.

Zaman, H. B., Mukti, N. A., Ariffin, S. R., \& Rahman, P. S. A. (1999). MEL: A multimedia based tutoring systems 
to motivate literacy. Language Reporter, 1(1).

\section{Copyrights}

Copyright for this article is retained by the author(s), with first publication rights granted to the journal.

This is an open-access article distributed under the terms and conditions of the Creative Commons Attribution license (http://creativecommons.org/licenses/by/3.0/). 